Article

\title{
Loose Ends in the Cortinarius Phylogeny: Five New Myxotelamonoid Species Indicate a High Diversity of These Ectomycorrhizal Fungi with South American Nothofagaceae
}

\author{
María Eugenia Salgado Salomón ${ }^{1,2,3, * \mathbb{D}}$, Carolina Barroetaveña ${ }^{1,2,3} \mathbb{D}$, Tuula Niskanen ${ }^{4}$, Kare Liimatainen ${ }^{4}$, \\ Matthew E. Smith ${ }^{5}$ (D) and Ursula Peintner 6
}

check for updates

Citation: Salgado Salomón, M.E.; Barroetaveña, C.; Niskanen, T.; Liimatainen, K.; Smith, M.E.; Peintner, $\mathrm{U}$. Loose Ends in the Cortinarius Phylogeny: Five New Myxotelamonoid Species Indicate a High Diversity of These

Ectomycorrhizal Fungi with South American Nothofagaceae. Life 2021, 11, 420. https://doi.org/10.3390/ life11050420

Academic Editors: Laura Selbmann, Armin Mešić and Ivana Kušan

Received: 31 March 2021

Accepted: 28 April 2021

Published: 5 May 2021

Publisher's Note: MDPI stays neutral with regard to jurisdictional claims in published maps and institutional affiliations.

Copyright: (c) 2021 by the authors. Licensee MDPI, Basel, Switzerland. This article is an open access article distributed under the terms and conditions of the Creative Commons Attribution (CC BY) license (https:// creativecommons.org/licenses/by/ $4.0 /)$.
1 Centro Forestal CIEFAP, CC 14, Ruta N 259 km 16.24, Esquel 9200, Argentina; cbarroetavena@ciefap.org.ar 2 Universidad Nacional de la Patagonia S.J. Bosco, Esquel Sarmiento 849, Chubut 9200, Argentina

3 Consejo Nacional de Investigaciones Científicas y Técnicas (CONICET), Godoy Cruz 2290, Buenos Aires 1425, Argentina

4 Jodrell Laboratory, Royal Botanic Gardens, Kew, Surrey TW9 3AB, UK; tuula.niskanen@cortinarius.fi (T.N.); k.liimatainen@kew.org (K.L.)

5 Department of Plant Pathology, University of Florida, P.O. Box 110680, Gainesville, FL 32611, USA; trufflesmith@ufl.edu

6 Institute of Microbiology, University Innsbruck, 6020 Innsbruck, Austria; Ursula.Peintner@uibk.ac

* Correspondence: mesalgadosalomon@ciefap.org.ar; Tel.: +54-2945-453948

Abstract: This paper is a contribution to the current knowledge of taxonomy, ecology and distribution of South American Cortinarius (Pers.) Gray. Cortinarius is among the most widely distributed and species-rich basidiomycete genera occurring with South American Nothofagaceae and species are found in many distinct habitats, including shrublands and forests. Due to their ectomycorrhizal role, Cortinarius species are critical for nutrient cycling in forests, especially at higher latitudes. Some species have also been reported as edible fungi with high nutritional quality. Our aim is to unravel the taxonomy of selected Cortinarius belonging to phlegmacioid and myxotelamonioid species based on morphological and molecular data. After widely sampling Cortinarius specimens in Patagonian Nothofagaceae forests and comparing them to reference collections (including holotypes), we propose five new species of Cortinarius in this work. Phylogenetic analyses of concatenated rDNA ITS-LSU and RPB1 sequences failed to place these new species into known Cortinarius sections or lineages. These findings highlight our knowledge gaps regarding the fungal diversity of South American Nothofagaceae forests. Due to the high diversity of endemic Patagonian taxa, it is clear that the South American Cortinarius diversity needs to be discovered and described in order to understand the evolutionary history of Cortinarius on a global scale.

Keywords: Telamonia; Chile; Argentina; hidden diversity; C. egonii; C. neuquensis; C. gracilentus; C. pseudoxiphidipus; C. voluptatis

\section{Introduction}

Cortinarius (Pers.) Gray is the most species-rich ectomycorrhizal genus in South American Nothofagaceae forests [1]. Due to their ectomycorrhizal role, Cortinarius species are critical for nutrient cycling in forests, especially at higher latitudes [2]. Additionally, some Cortinarius species, including C. magellanicus Speg. complex, C. xiphidipus Moser and Horak, C. austroturmalis Moser and Horak, C. pugionipes Moser and Horak, C. effundens Moser and Horak, C. cervinus Moser and Horak or C. lebre Garrido, have been reported to be edible and of high nutritional quality [3-6]. Several species are also renowned for their antioxidant, antimicrobial and acidifying properties [3,7].

Even though several authors have contributed to the knowledge of Cortinarius associated with South American Nothofagaceae forests ([5,8-22], among others), the biodiversity of this genus in the Southern Hemisphere is incredibly high and remains insufficiently 
studied $[23,24]$. Recent studies showed, for example, that $C$. magellanicus, which was previously reported as widely distributed and shared among various Nothofagaceae hosts in the Southern Hemisphere [5,6,25-29], is a complex of species. The C. magellanicus group is composed of at least four phylogenetic lineages, each with strong regionalism and distinct host associations [15].

Phylogenetic analyses have helped to delimit taxonomic entities within Cortinarius $[16,23,30-39]$ and have shown that many morphologically delimited subgenera and/or sections represent unnatural groups [23,24,31,37,40-43]. In particular, section Myxotelamonia was proposed by Moser et al. [5] (p. 22) for endemic telamonioid Cortinarius species from South America. These telamonioid taxa all have a clearly gelatinized epicutis with grayish tints in the lamellae but they are from different subgenera [24] (p. 1049). This paper is a contribution to the current knowledge of South American Cortinarius taxonomy, ecology, and distribution. The aim of this paper is to describe five new Cortinarius species based on morphological and molecular data. Moreover, we tried to place these myxotelamonioid species into Cortinarius sections or phylogenetic lineages, but we were not successful due to the lack of closely related reference sequences. As a first step, the South American Cortinarius diversity needs to be discovered and described. We regard these South American taxa as essential puzzle pieces that are necessary for understanding the evolutionary history of Cortinarius on a global scale.

\section{Materials and Methods}

\subsection{Field Work}

Samples of Cortinarius specimens were collected in Nothofagaceae spp. forests in Argentina and Chile during three consecutive mushroom seasons (2015-2017) (Table 1). Study sites were in NW Patagonia of Argentina and Chile, in habitats of the Sub-Antarctic Province, Sub-Antarctic Domain [44].

\subsection{Morphological Study}

Macroscopic descriptions were made from fresh basidiomata. Colours of the basidiomes were documented with a color code [45]. UV recordings were made on fresh and dried (exsiccatae) basidiomata using a $366 \mathrm{~nm}$ UV lamp. $\mathrm{KOH}$ reactions, where relevant, were made on dried basidiomata [46]. Microscopic data were documented with a Nikon camera D70 in combination with the computer program LASX (https: / / www.leica-microsystems.com 1 April 2017) and ImageJ (https:/ / imagej.nih.gov / accessed on 05 May 2021). Microscopic characteristics are from dried specimens (exsiccatae) revived in 3\% $\mathrm{KOH}$, sulpho-vanillin, Melzer's reagent or cotton blue following [47] (pp. 43-114). The possible dextrinoid reaction of basidiospores was observed from pieces of lamellae placed in Melzer's reagent for five minutes. Basidiospore measurements ( $n \geq 80)$ were made in $3 \% \mathrm{KOH}$ from basidiospores taken from the spore deposits from the apex of the stipe and veil tissue. For statistical evaluation, 125 to 150 spores were measured. Spore measurements are given as (min) mean \pm standard deviation (max). Studied material is deposited in the IB, HCFC and CORD herbaria (Table 1). 
Table 1. Material included in this study including ecological and habitat data, herbarium and GenBank/UNITE numbers.

\begin{tabular}{|c|c|c|c|c|c|c|}
\hline Species & Site & Associated Species & GenBank/UNITE Number & Herbaria Number & Type & Sampling Date \\
\hline Cortinarius avellaneus & Argentina, Neuquén, PNNH, Puerto Manzano & Nothofagus dombeyi $+N$. pumilio & UDB023898 & IB 19630368 & Type & $18 / 4 / 1963$ \\
\hline Cortinarius caryotis & Unknown & Unknown & KJ421039 & F44422 & & Unknown \\
\hline Cortinarius caryotis & New Zealand, Hawdon (Cass) & Nothofagus spp. & GU233348 & PDD 71004 & Holotype & $21 / 4 / 1999$ \\
\hline Cortinarius caryotis & New Zealand, UNP *, Lake Waikareiti Track & Unknown & GU233356 & PDD 74305 & & $11 / 5 / 2001$ \\
\hline Cortinarius cinereus & Chile, Coyhaique & Nothofagus dombeyi & MH511098 & CONCF0650 & & $15 / 3 / 2007$ \\
\hline Cortinarius cinereus & Argentina, Río Negro, PNNH **, Valle Frías & Nothofagus dombeyi & UDB023853 & IB 19630117 & Type & $21 / 3 / 1963$ \\
\hline Cortinarius cinereus & Chile & Unknown & UDB034963 & IBFFG 650 & & Unknown \\
\hline Cortinarius dulcamarus & New Zealand, North Canterbury, Medbury Scientific Reserve & Kunzea ericoides & MH101559 & PDD 96951 & & $26 / 5 / 2013$ \\
\hline Cortinarius egonii & Chile, Aysen, Carretera Austral, south of Bertrand port. & Nothofagus pumilio $+N$. dombeyi & MT925625 & CT4418/FLAS-F-63487 & & $3 / 5 / 2016$ \\
\hline Cortinarius egonii & Argentina, Río Negro, PNNH, Steffen lake & Nothofagus dombeyi & MN707588 & HCFC C246/IB 20170447 & & $16 / 5 / 2017$ \\
\hline Cortinarius egonii & Argentina, Río Negro, PNNH, Steffen lake & Nothofagus dombeyi & MN707589 & HCFC C257/IB 20170257 & Holotype/Isotype & $16 / 5 / 2017$ \\
\hline Cortinarius egonii & Argentina, Río Negro, PNNH, Steffen lake & Nothofagus dombeyi & MN707590 & HCFC C258/IB 20170258 & & $16 / 5 / 2017$ \\
\hline Cortinarius egonii & Argentina, Chubut, PNLA ${ }^{* * *}$, Colihual stream & Nothofagus dombeyi & MN707571, MW405257 & HCFC C52/IB 20170324 & & $11 / 4 / 2017$ \\
\hline Cortinarius egonii & Argentina, Chubut, PNLA, Colihual stream & Nothofagus dombeyi & $\begin{array}{l}\text { MN707574, MW405256, } \\
\text { MW546832 }\end{array}$ & HCFC C80/IB 20170342 & & $18 / 4 / 2017$ \\
\hline Cortinarius egonii & $\begin{array}{l}\text { Argentina, Río Negro, Bariloche, Nahuel Huapi National Park, Los } \\
\text { Rápidos }\end{array}$ & Nothofagus dombeyi + N. antarctica & МT925623 & $\begin{array}{c}\text { MES-1205 } \\
\text { CORDC00006881 } \\
\end{array}$ & & $11 / 5 / 2016$ \\
\hline Cortinarius egonii & $\begin{array}{c}\text { Argentina, Río Negro, Bariloche, PNNH, Goye stream, near Colonia } \\
\text { Suiza }\end{array}$ & Nothofagus dombeyi $+N$. pumilio & KY462608 & MES-1888/CORDC00005629 & & $12 / 5 / 2016$ \\
\hline Cortinarius egonii & Argentina, Río Negro, Bariloche, PNNH, Road to Tronador & Nothofagus pumilio & MT925622 & $\begin{array}{c}\text { MES-2001 } \\
\text { CORDC00005551 }\end{array}$ & & $14 / 5 / 2016$ \\
\hline Cortinarius gracilentus & Argentina, Chubut, PNLA, Camping area & Nothofagus antarctica & MN707580, MW405251 & HCFC C171/IB 20170235 & & $25 / 4 / 2017$ \\
\hline Cortinarius gracilentus & Argentina, Chubut, PNLA, Rivadavia river & Nothofagus dombeyi & MN707572 & HCFC C66/IB 20170334 & Holotype/Isotype & $18 / 4 / 2017$ \\
\hline Cortinarius 'gymnopiloides' & New Zealand & Unknown & AF389147 & ZT NZ68501 & Type & Unknown \\
\hline Cortinarius macilentus & Argentina, Río Negro, PNNH, Valle Frías & Nothofagus dombeyi & UDB023869 & IB19630184 & Type & $24 / 3 / 1963$ \\
\hline Cortinarius micaceus & Argentina, Río Negro, PNNH, Valle Frías & $\begin{array}{c}\text { Nothofagus dombeyi }+N . \text { antarctica }+N . \\
\text { pumilio }\end{array}$ & UDB023868 & IB 19630182 & Type & 20/3/1963 \\
\hline Cortinarius mitis & Argentina, Río Negro, PNNH, Valle Frías & Nothofagus dombeyi & UDB023858 & IB19630139 & Type & $22 / 3 / 1963$ \\
\hline Cortinarius neuquensis & Argentina, Bariloche, PNNH, along road halfway to Tronador. & Nothofagus antarctica & MT925952 & MES-1148 CORDC00005190 & & 9/5/2015 \\
\hline Cortinarius neuquensis & Argentina, Neuquén, PNL ${ }^{* * * *}$, Norquinco Lake & Lophozonia alpina + L. obliqua & MN707581 & HCFC C196 IB 20170218 & & $3 / 5 / 2017$ \\
\hline Cortinarius neuquensis & Argentina, Neuquén, Chañy Protected Area, Chañy stream & Nothofagus antarctica + A. araucana & MN707582 & HCFC C206 IB 20170222 & Holotype/Isotype & $4 / 5 / 2017$ \\
\hline Cortinarius neuquensis & Argentina, Neuquén, Chañy Protected Area, Chañy stream & N. antarctica + A. araucana & $\begin{array}{l}\text { MN707583, MW405255, } \\
\text { MW546831 }\end{array}$ & HCFC C210 IB 20170224 & & $4 / 5 / 2017$ \\
\hline Cortinarius neuquensis & Chile, Osorno, PNP *****, last stop near Aguas Calientes & Nothofagus dombeyi & MT925953 & MES-1551 FLAS-F-64363 & & $3 / 5 / 2016$ \\
\hline Cortinarius neuquensis & $\begin{array}{l}\text { Chile, Osorno, PNP, foothills of Volcan Puyehue, up the road past El } \\
\text { Caulle north of Rio Golgol }\end{array}$ & Nothofagus dombeyi & KY462509 & MES-1638 FLAS-F-64429 & & $4 / 5 / 2016$ \\
\hline
\end{tabular}


Table 1. Cont

\begin{tabular}{|c|c|c|c|c|c|c|}
\hline Species & Site & Associated Species & GenBank/UNITE Number & Herbaria Number & Type & Sampling Date \\
\hline Cortinarius neuquensis & Argentina, Bariloche, PNNH, Road to Tronador & Nothofagus antarctica & MT925951 & MES-2009 CORDC00005547 & & $14 / 5 / 2016$ \\
\hline Cortinarius neuquensis & Chile & Lophozonia alpina & KY462703 & MES-988 FLAS-F-63016 & & Unknown \\
\hline Cortinarius nitellinus & Argentina, Neuquén, PNNH, Puerto Manzano & Nothofagus dombeyi & UDB023833 & IB19630044 & Type & $12 / 3 / 1963$ \\
\hline Cortinarius 'perelegans' & New Zealand & Unknown & JX178615 & OTA 60285 & & Unknown \\
\hline Cortinarius pseudoxiphidipus & Argentina, Chubut, PNLA, Rivadavia river & Nothofagus dombeyi & $\begin{array}{l}\text { MN707573, MW405254, } \\
\text { MW546828 }\end{array}$ & $\begin{array}{l}\text { HCFC C78 } \\
\text { IB } 20170340\end{array}$ & & $18 / 4 / 2017$ \\
\hline Cortinarius pseudoxiphidipus & Argentina, Chubut, PNLA, Rivadavia river & Nothofagus dombeyi & MN707575, MW405252 & $\begin{array}{l}\text { HCFC C } 88 \\
\text { IB } 20170347\end{array}$ & Holotype/Isotype & $18 / 4 / 2017$ \\
\hline Cortinarius pseudoxiphidipus & Argentina, Chubut, PNLA, Rivadavia river & Nothofagus dombeyi & $\begin{array}{l}\text { MN707576, MW405253, } \\
\text { MW546829 }\end{array}$ & $\begin{array}{l}\text { HCFC C90 } \\
\text { IB } 20170441\end{array}$ & & $18 / 4 / 2017$ \\
\hline Cortinarius rhodophyllus & Unknown & Unknown & KJ421051 & TUB 020416 & & Unknown \\
\hline Cortinarius rufus & Argentina, Neuquén, PNNH, Puerto Manzano & N. pumilio & MF568564 & IB19630369 & Type & $18 / 4 / 1963$ \\
\hline Cortinarius rufus & Argentina, Río Negro, PNNH, Arroyo Goye near Colonia Suiza & Nothofagus dombeyi $+N$. pumilio & MF568565 & $\mathrm{K}(\mathrm{M}) 234990$ & & $12 / 5 / 2016$ \\
\hline Cortinarius semiamictus & Argentina, Río Negro, Paso de las Nubes, Frías Valley & Nothofagus dombeyi + N. antarctica & UDB023828 & IB 19620161 & Type & $7 / 4 / 1962$ \\
\hline Cortinarius sp. & Australia & Unknown & MG553066 & PERTH:06435416 FC393 & & Unknown \\
\hline Cortinarius sp. & $\begin{array}{l}\text { Chile, Osorno, PNP, foothills of Volcan Puyehue, up the road past El } \\
\text { Caulle north of Rio Golgol }\end{array}$ & Nothofagus dombeyi & KY462487 & MES-1597 FLAS-F-64397 & & Unknown \\
\hline Cortinarius sp. & $\begin{array}{l}\text { Chile, Osorno, PNP, foothills of Volcan Puyehue, up the road past El } \\
\text { Caulle north of Rio Golgol }\end{array}$ & Nothofagus dombeyi & KY462492 & MES-1602 FLAS-F-64401 & & Unknown \\
\hline Cortinarius sp. & $\begin{array}{l}\text { Chile, Osorno, PNP, foothills of Volcan Puyehue, up the road past El } \\
\text { Caulle north of Rio Golgol }\end{array}$ & Nothofagus dombeyi & KY462567 & $\begin{array}{l}\text { MES-1801 } \\
\text { FLAS-F-64558 }\end{array}$ & & Unknown \\
\hline Cortinarius subrufus & Argentina, Río Negro, PNNH, Hess lake & Nothofagus antarctica & MF568560 & $\mathrm{K}(\mathrm{M}) 235093$ & & $17 / 5 / 2016$ \\
\hline Cortinarius subrufus & Chile, Magallanes, Karukinka Reserve, Vicuña station & Nothofagus antarctica & MF568561 & $\mathrm{K}(\mathrm{M}) 235583$ & & $27 / 3 / 2017$ \\
\hline Cortinarius subrufus & Chile, Magallanes, Karukinka Reserve, Vicuña station & Nothofagus antarctica & MF568562 & $\mathrm{K}(\mathrm{M}) 235584$ & & $26 / 3 / 2017$ \\
\hline Cortinarius verniciorum & New Zealand, Fiordland, Te Anau Downs Motel & Leptospermum, possibly Nothofagus & JQ287679 & PDD 94010 & & $25 / 4 / 2008$ \\
\hline Cortinarius verniciorum & New Zealand, Fiordland, Te Anau Downs Motel & Leptospermum, possibly Nothofagus & NR157876 & PDD 94010 & Type & $25 / 4 / 2008$ \\
\hline Cortinarius viscilaetus & New Zealand, Totara, Milford Road & Nothofagus spp. & KT875206 & PDD 107734 & & $18 / 5 / 2015$ \\
\hline Cortinarius viscilaetus & New Zealand, Te Anau, Kepler Track & Nothofagus spp. & GU233353 & PDD 71010 & Type & 18/4/1997 \\
\hline Cortinarius voluptatis & Argentina, Chubut, PNLA, Rivadavia Camping area & Nothofagus antarctica & MN707579 & CIEFAP157/IB 20170109 & & $25 / 4 / 2017$ \\
\hline Cortinarius voluptatis & Argentina, Neuquén, PNL, Yuco region & Lophozonia alpina + L. obliqua & MN707584, MW405260 & HCFC C218/IB 20170229 & & $5 / 5 / 2017$ \\
\hline Cortinarius voluptatis & Argentina, Neuquén, PNL, Yuco region & Lophozonia alpina + L. obliqua & $\begin{array}{l}\text { MN707585, MW405258, } \\
\text { MW546830 }\end{array}$ & HCFC C219/IB 20170231 & Holotype/Isotype & $5 / 5 / 2017$ \\
\hline Cortinarius voluptatis & Argentina, Neuquén, PNL, Yuco region & Lophozonia alpina + L. obliqua & MN707587, MW405259 & HCFC C230/IB 20170238 & & $5 / 5 / 2017$ \\
\hline Uncultured Cortinarius & Argentina, Neuquén, PNL, Yuco region & Lophozonia alpina & KJ701302 & Environmental & & Unknown \\
\hline Uncultured fungus & Argentina & Nothofagus pumilio & JX316449/UDB008462 & Environmental & & Unknown \\
\hline Uncultured fungus & Argentina & Lophozonia alpina & JX316363 & Environmental & & Unknown \\
\hline
\end{tabular}

UNP *: Urewera National Park, PNNH **: Nahuel Huapi National Park, PNLA *** Los Alerces National Park, PNL ${ }^{* * * *}$ : Lanín National Park, PNP ${ }^{* * * * *: ~ P u y e h u e ~ N a t i o n a l ~ P a r k . ~}$ 


\subsection{DNA Extraction, PCR Amplification and Sequencing}

To establish phylogenetic relationships, ITS-rDNA sequences were produced as previously described [44] using the primers ITS1 and ITS4 [48]. The rDNA LSU region was amplified with the primer combination LR0R and LR05 [48]. PCR amplifications of RPB1 domains A-C were made with the primer combination RPB1-A and RPB1-C [49]. Sequences were assembled and edited with Sequencher 4.1 (Gene Codes, Ann Arbor, Mich., USA). As a first step, a Blast search was conducted in UNITE (https:/ / unite.ut.ee 1 April 2017). Sequences of closely related Cortinarius species were then downloaded from GenBank (http:/ /ncbi.nlm.nih.gov 1 April 2017) and UNITE. ITS sequences from several types of specimens were also included in the study (Table 1). A total of 28 ITS sequences from the five new species were produced for this study. In addition, eleven LSU sequences and five RPB1 sequences were generated. The newly generated sequences were submitted to GenBank under the accession numbers MN707570-90, MT925622-25; MT925951-53, MW546828-32.

\subsection{Data Analysis}

Data analysis was carried out in a two-step process: A first analysis was based on ITS rDNA sequences only. The best reference sequence database is available for this DNA barcoding region, including sequences from several Patagonian holotypes. As a second step, we aimed at placing our terminal clades into known Cortinarius sections or lineages based on concatenated ITS-LSU and ITS-LSU-RPB1 sequences. This was done separately due to the fact that different reference sequences were available for the LSU and RPB1 markers.

A total of 64 rDNA ITS sequences were aligned and manually adjusted in MEGA $X$ [50]. Reference sequences were selected and downloaded for closely relates species based on morphology or based on sequence similarity resulting from BLAST analyses. The evolutionary history was inferred by using the Maximum Likelihood method based on the Hasegawa-Kishino-Yano model $+\mathrm{G}$, parameter $=0.2332$. All positions with less than $95 \%$ site coverage were eliminated. There was a total of 560 positions in the final dataset.

To evaluate the robustness of the branches in the phylogenetic trees, parsimonybased bootstrap analyses were applied. The bootstrap analyses were conducted using 1000 replications, an SPR search method, and search level 5. The alignment is composed of 653 nucleotides (including gaps). Bayesian Posterior Probabilities were calculated with $\mathrm{Mr}$ Bayes 3.2. [51]. Bayesian analysis was carried out with two independent four-chain runs, sampling over 2 million generations.

In addition, two combined phylogenetic analyses were carried out: the first was based on rDNA data only (ITS and LSU), and the second on a combined dataset containing combined sequences spanning RPB1 regions, the ITS regions, and about 600 bases of the 5 '-terminal large subunit (LSU) domain (D1/D2). The alignment of the combined ITS and LSU data contained 1328 positions, and 52 taxa. ML analysis was carried out based on the best model $(G T R+G$ parameter $=0.2131)$ and 1164 positions were analyzed. The tree with highest log likelihood was -10619.28. The alignment of the combined RPB1, ITS, and LSU sequences contained 99 sequences and 2773 positions after the exclusion of ambiguous regions. ML analysis was carried out based on the best model (Tamura 3-parameter $+\mathrm{G}$, parameter $=0.2462$ ), and 1697 positions were analyzed. Two separate Mr Bayes runs were run under the general time-reversible model with gamma-distributed rate variation. Runs included four incrementally heated chains that were run for 10 million generations each, sampling every 100th generation and with the first 2.5 million generations discarded as burn-in. For further evaluation of branch robustness, parsimony-based bootstrap analyses were applied as described above, with 1000 replications.

Statistical analyses were performed with the width, length, and volume of spores. The width, length, and volume of spores between the species did not meet the assumptions of normal distribution and equal variances using the Shapiro-Wilk and Levene tests [52]. 
Therefore, differences in the width, length, and volume of spores between species were analyzed using non-parametric Kruskal-Wallis ANOVAs performed at the 0.05 significance level, using the statistical package InfoStat for Windows version 2017 [53]. Test for normal distribution and QQ-Plots were performed with R package (R Core Team 2019).

\section{Results}

\subsection{Molecular Data}

The ITS-based phylogeny with the best ML log likelihood -2174.22 allowed for the best comparison to available reference sequences, including sequences generated from type specimens. All five species described here form well-supported clades (Bayesian posterior probability $(\mathrm{BPP})>0.99$, Bootstrap Score $(\mathrm{BS})>95 \%$ ) in the ITS phylogeny (Figure 1). The sister-group relationships are well-resolved in $C$. gracilentus only, where closely related reference sequences of $C$. avellaneus are available. Cortinarius egonii is sister to $C$. rhodophyllus Moser \& Horak $(\mathrm{BPP}=0.95)$, but only one reference sequence is available for $C$. rhodophyllus, but it was not obtained from type material. The ITS sequence generated from the type of section Myxotelamonia, C. cinereobrunneus IB19630258, could not be aligned with the sequences of the five new species, showing that these new species do not belong to section Myxotelamonia. The most closely related sequences from Moser and Horak's South American holotypes were C. mitis (Subgenus Myxacium, Section Ochroleuci), which is related to the clade with the new species $C$. neuquensis $(\mathrm{BPP}=0.83$ ); C. micaceus (subgenus Sericeocybe strips Nothoanomalus), C. cinereus (Section Telamonia) and C. nitellinus (Section Formiores) are weakly related to the new species C. voluptatis $(\mathrm{BPP}=0.77$ ); and C. avellaneus (Section Myxotelamonia), C. semiamictus (Subgenus Paramyxacium, stirps Myxacioides) and C. macilentus (Section Myxotelamonia) are related to the new species C. gracilentus (BPP $=1.00)$.

The concatenated analysis of the LSU-ITS rDNA and RPB1 regions (best ML tree with $\log$ likelihood -17366.88) indicates a possible common origin for C. pseudoxiphidipus, C. voluptatis and C. egonii (BPP 0.929). Our data also suggest that $C$. neuquensis could be related to a clade containing C. lustratus Fr., C. cretax Soop and C. pinophilus Soop (BPP 0.871) (Supplementary Figure S1).

\subsection{Taxonomic Data}

All the species included in the morphological study differ significantly in the dimensions of their spores (Kruskal Wallis, $\mathrm{H}=1957.22, p<0.0001$ ), confirming statistically different clouds of data (Figure 2). Statistical analysis of basidiospore measurements confirmed that the spores of $C$. neuquensis are significantly smaller (in both width and length) than spores of other Cortinarius species from this study. On the other hand, C. voluptatis' spores are significantly bigger (in both width and length) from any other species in this study (Kruskal Wallis, $\mathrm{H}=1957.22, p<0.0001$, Figure 3 ). All species can clearly be separated from each other based on their spore size and shape (as a function of $Q=$ length/with).

\subsection{Taxonomy}

3.3.1. Cortinarius egonii Salgado Salomón, Peintner, Liimat. and Niskanen spp. nov. MycoBank MB 836828

Etymology

The species epithet refers to Dr. Egon Horak, globally recognized expert on the genus Cortinarius. His work has inspired many mycologists around the world to discover the fascinating world of Cortinarius taxonomy, including the authors of this paper.

\section{Diagnosis}

Cortinarius egonii (Figures $4 \mathrm{D}$ and $5 \mathrm{C}$ ) has medium-sized basidiomata (pileus: 2.7$4.4 \mathrm{~cm}$ in diam.; stipe: $3.7-5.0 \times 0.5-0.6 \mathrm{~cm}$ ) and is characterized by a glutinous pileus with pale yellow to maize colors and a darker, brown center; elliptical, inconspicuously verrucose (6.3)7.5-8.9(10.4) $\times(4.2) 4.8-5.5(6.6) \mu \mathrm{m}$ spores and the presence of melanized, thick-walled hyphae with a diam. of (3)4-7 $\mu \mathrm{m}$ in the context. 


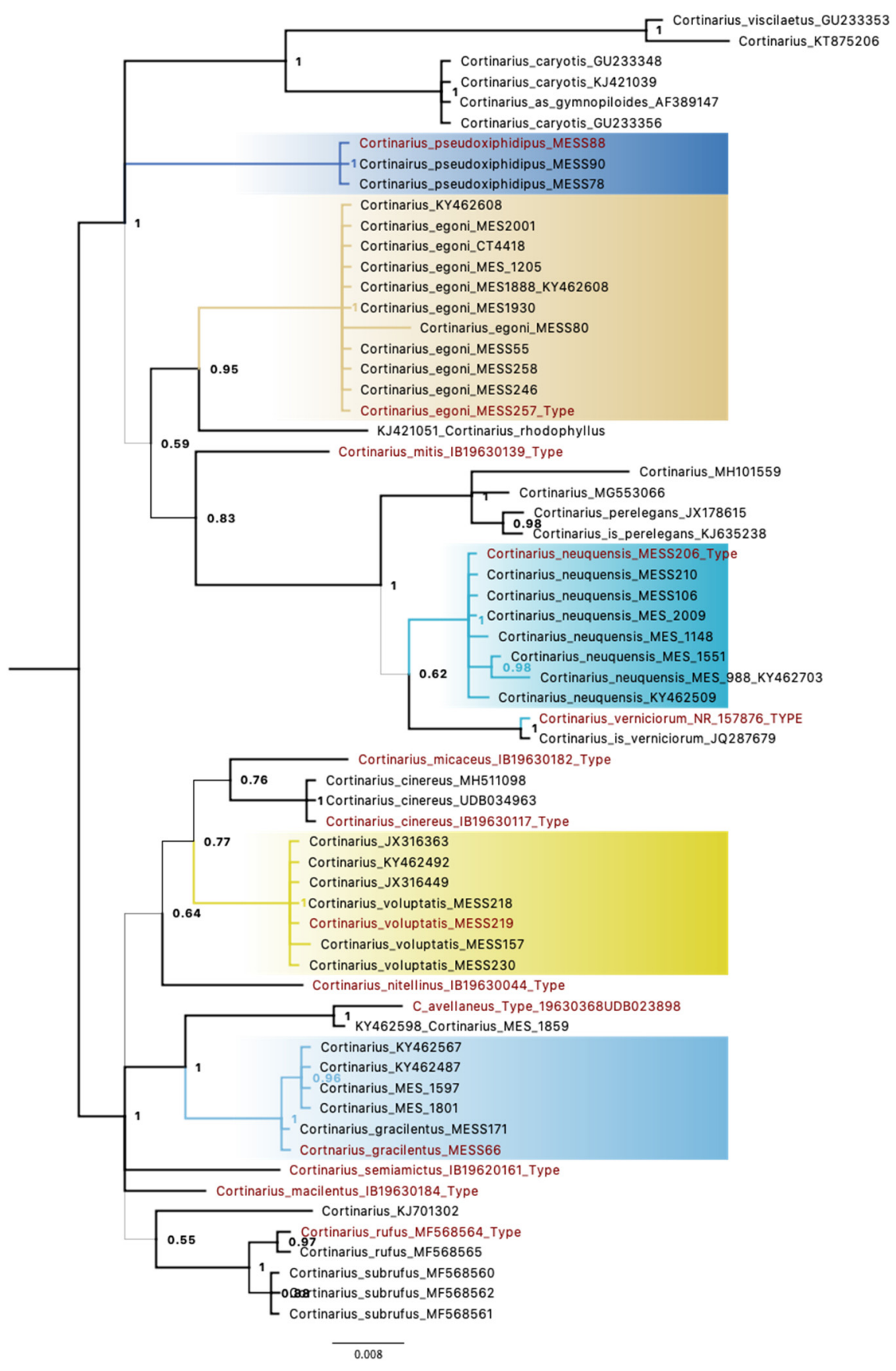

Figure 1. Phylogenetic relationships of the five new species of Cortinarius from South American Nothofagaceae forests based on rDNA ITS sequences. Bayesian posterior probabilities are provided beside each node. Sequences generated from type material are highlighted in red. 


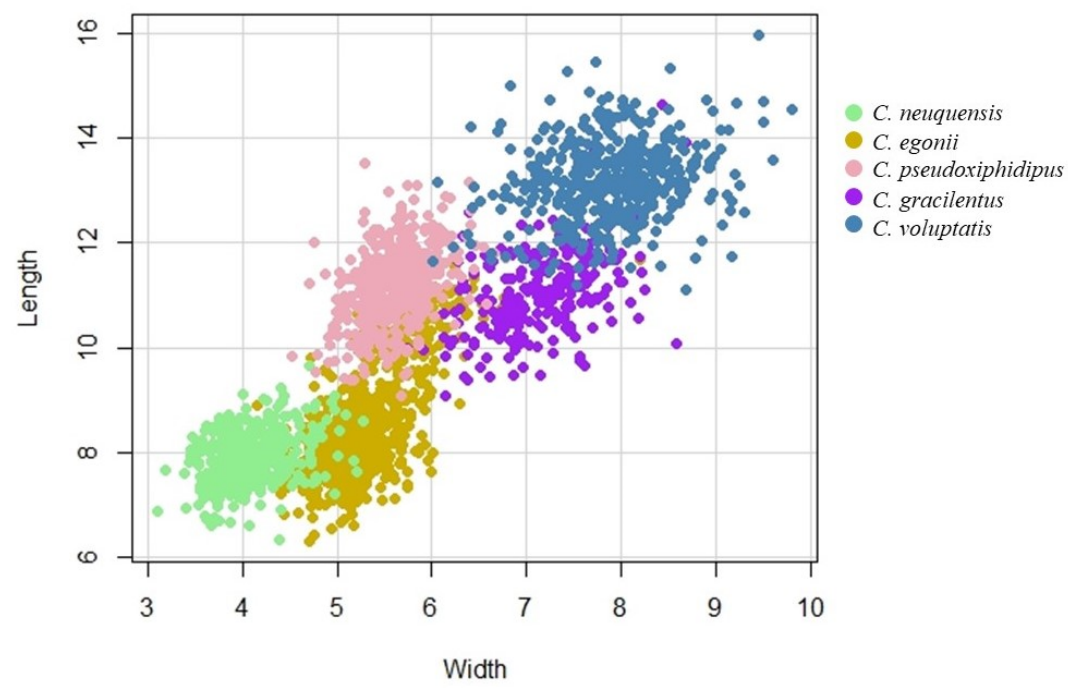

Figure 2. Scatterplot of spore length and width for the five newly described Cortinarius species.
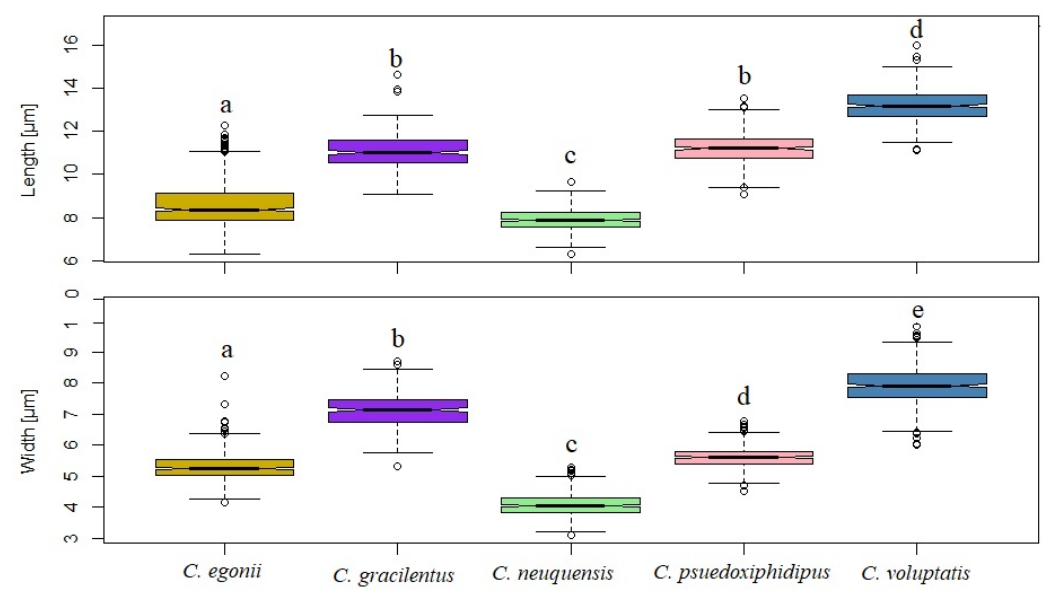

Figure 3. Boxplot of spore lengths and widths for the five newly described Cortinarius species. Different letters indicate significant differences in the means $(p<0.0001)$ based on Kruskall Wallis tests.
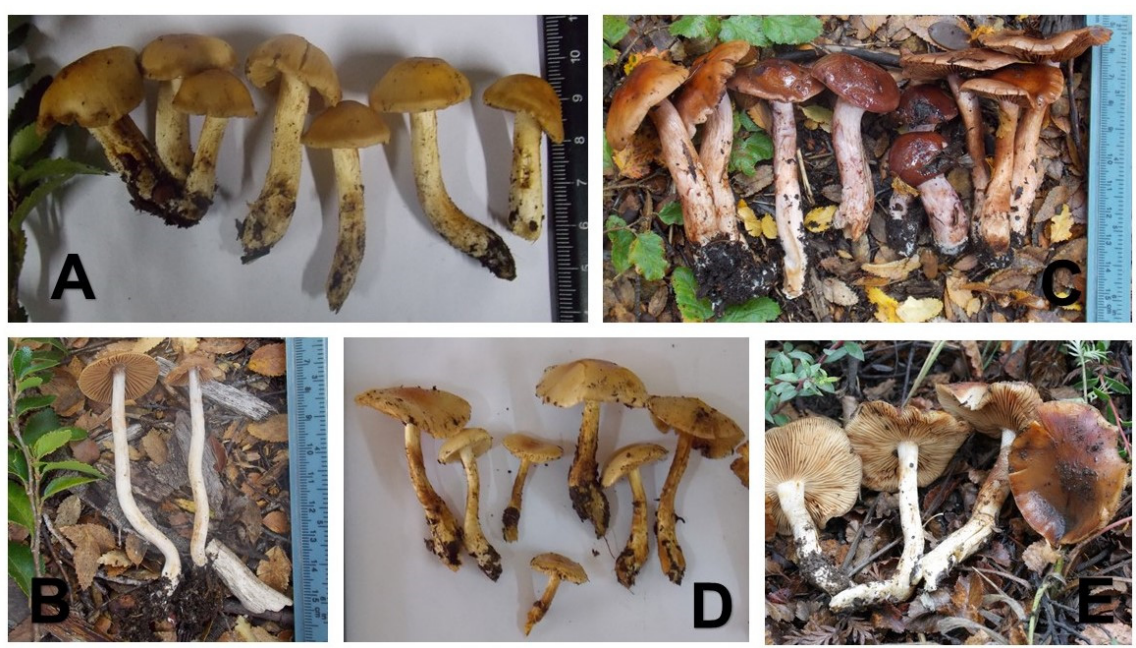

Figure 4. New Cortinarius species proposed. Photos of basidiomata. (A) C. pseudoxiphidipus. (B) C. gracilentus. (C) C. voluptatis. (D) C. egonii. (E) C. neuquensis. Photos (A-D) by MESS, photo E by PB Matheny. 


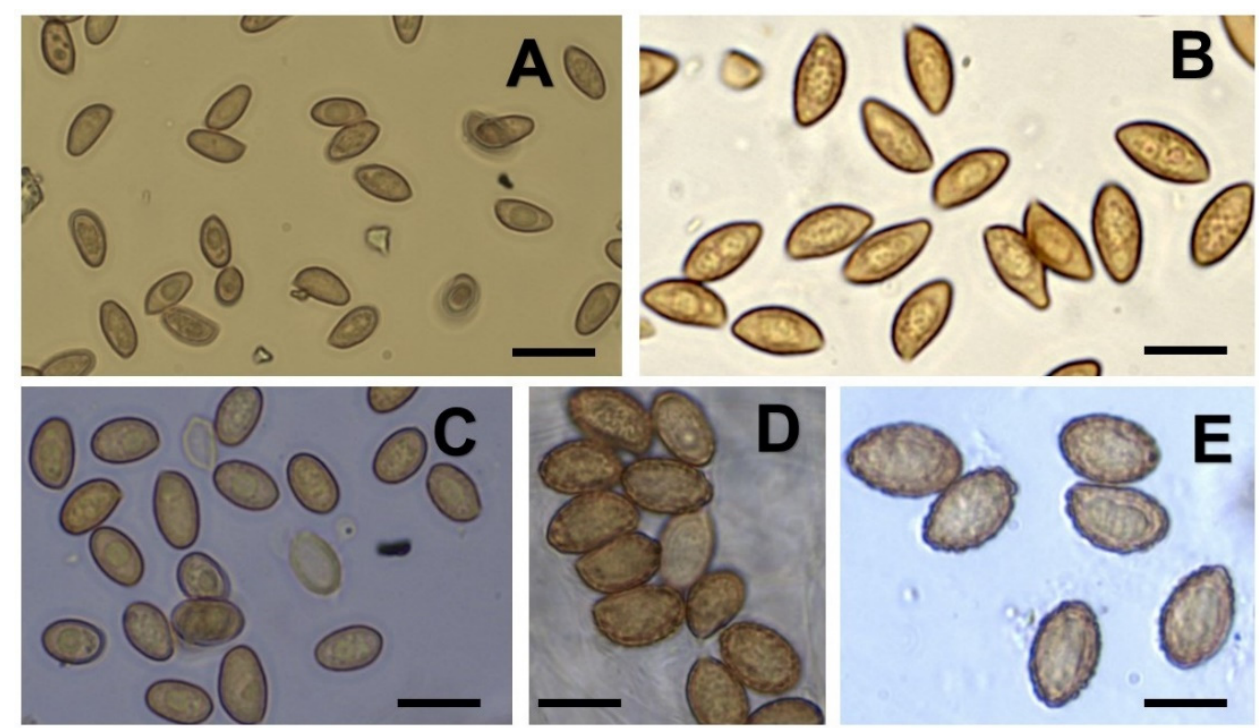

Figure 5. Basidiospores of the new Cortinarius species proposed. Photos of (A) C. neuquensis. (B) C. pseudoxiphidipus. (C) C. egonii. (D) C. gracilentus. (E) C. voluptatis. The bar represents $10 \mu \mathrm{m}$.

Type

Argentina, Río Negro, Bariloche, Nahuel Huapi National Park, Steffen lake, Coordinates Lat.: -41.3062; Long.: -71.3207; Alt.: 571.5 m.a.s.l. Associated with Nothofagus dombeyi, leg. et det. María Eugenia Salgado Salomón, Holotype: HCFC C257; Isotype: IB 20170257, 16 May 2017, Genbank acc. No. MN707589.

\section{Macrocharacters}

PILEUS 2.7-4.4 cm in diam., convex in young specimens, hemispherical to convex and plano-convex with age, pileus margin slightly bent, in young specimens slightly involute. Pileus surface glutinous, slightly hygrophanous, smooth. Pileus color varies between cream (9D2) to cork (13B7) at the margin with clearly darker colors towards the pileus center ranging between artificial brown (8L6) and Tuscany brown (7L11-7L12), later mixed with an orange tone.

LAMELLAE sinuated to adnate, on average dense, about 14-15 lamellae per $\mathrm{cm}$, margin entire to finely eroded. Color of the lamellae at the pileus margin when young cream (9D2) to corn (10J5), becoming terracotta colored with age (4D12).

STIPE 3.7-5.0 $\times 0.5-0.6 \mathrm{~cm}$, cylindrical to clavate, longitudinally fibrous, dry, white (10B1-10C1), with yellowish with remnants of a universal veil; Cortina evanescent, white in young specimens, disappearing with age.

Context ochraceous when fresh, with paler colors towards the margin of the stipe. Smell fungal to sweetish in gills. Taste mild. Usually growing in groups but not cespitose.

Macrochemical reactions: $20 \% \mathrm{KOH}$ negative on exsiccate. No fluorescence was detected at $350 \mathrm{~nm}$ nor at $254 \mathrm{~nm}$ (in exsiccate material).

\section{Microcharacters}

Basidiospores (6.3) 7.5-8.9 (10.4) $\times(4.2) 4.8-5.5(6.6) \mu \mathrm{m}$. (mean \pm sd: $8.2 \pm 0.5 \times 5.2$ $\pm 0.3 \mu \mathrm{m}$, Q: (1.3) $1.6 \pm 0.2(2.1) ;(n=142)$ for holotype. Elliptical, subcylindrical, very slightly ornamented, inconspicuously verrucose, not dextrinoid, pale bronze brown.

BASIDIA with four sterigmata, occasionally 2 -sterigmata and basal clamp connection, clavate, (26) 27-30 (31) × (6) 7-9 $\mu \mathrm{m}$, sterigmata 3-4 $\mu \mathrm{m}$ long $(n=10)$.

CHEILOCYSTIDIA present, clavated, (31) 32-37 (39) $\times 6-9 \mu \mathrm{m}(n=16)$.

LAMELLAR TRAMA consisting of parallel hyaline clamped hyphae with a diam. of (4)5-8(11) $\mu \mathrm{m}(n=25)$, thin walled. 
PILEIPELLIS with a $160 \mu \mathrm{m}$ wide gelatinous layer, consisting of hyaline hyphae with a diam. of 4-6 $\mu \mathrm{m}(n=20)$ and clamp connections.

PILEUS CONTEXT 800-900 $\mu$ m wide, formed by two layers. Uppermost with inflated hyphae elements with a diam. of (11)15-31 (45) $\mu \mathrm{m}(n=37)$, spongy looking, hyaline, colorless, thin-walled, hyphal walls not encrusted. Intermediate layer with hyphae of a diam. of (8)9-12(15) $\mu \mathrm{m}(n=30)$, hyaline, colorless, thin-walled, hyphal walls not encrusted. None of the two layers is staining with 3\% KOH, cotton blue, Melzer's reagent or Sulphovanillin. Within the regular layer of the context, there are non-clamped oleiferous-like hyphae of amber colors (10I6 to 10J6; in 3\% $\mathrm{KOH}$ ) they are thick-walled and somewhat irregular with a diam. of (3)4-6(7) $\mu \mathrm{m}(n=16)$. They do not stain with cotton blue, Melzer's reagent or Sulpho-vanillin.

Clamp connections present in all tissues.

Ecology and Distribution

Forest type-Nothofagus dombeyi, N. pumilio and N. antarctica; observed in May. The monthly average temperature for May in the area is $8{ }^{\circ} \mathrm{C}\left(\max / \min 13 / 5^{\circ} \mathrm{C}\right)$, with a total of $95 \mathrm{~mm}$ precipitation (weather station El Bolsón Aero, data from 2017). Soil pH = 5.8.

Other material examined: Argentina, Chubut, Futaleufú, Los Alerces National Park, Arroyo Colihual, Coordinates Lat.: -42.7005 W; Long.: -71.7041. Associated with Nothofagus dombeyi, leg. et det. María Eugenia Salgado Salomón, herbaria number HCFC C52/IB 20170324; 11 April 2017, Genbank acc. No. MN707571.

Argentina, Río Negro, Bariloche, Nahuel Huapi National Park, Steffen lake, Coordinates Lat.: -41.3071; Long.: -71.3237; Alt.: 551 m.a.s.l. Associated with Nothofagus dombeyi, leg. et det. María Eugenia Salgado Salomón, herbaria number HCFC C246/IB 20170447; 16 May 2017, Genbank acc. No. MN707588.

Argentina, Río Negro, Bariloche, Nahuel Huapi National Park, Steffen lake, Coordinates Lat.: -41,3062; Long.: -71,3207; Alt.: 571.5 m.a.s.l. Associated with Nothofagus dombeyi, leg. et det. María Eugenia Salgado Salomón, herbaria number HCFC C258/IB 20170258; 16.05.2017, Genbank acc. No. MN707590.

Argentina, Río Negro, San Carlos de Bariloche, Nahuel Huapi National Park, Arroyo Goye, near Colonia Suiza, Coordinates Lat.: -42.7005 W; Long.: -71.7041. Associated with Nothofagus dombeyi and N. pumilio, leg. Tuula Niskanen et al., herbaria number MES-1888, CORDC00005629; 12.05.2016, Genbank acc. No. KY462608.

Argentina, Río Negro, Bariloche, Nahuel Huapi National Park, Road to Tronador, just before the mountain base. Associated with Nothofagus pumilio, leg. Tuula Niskanen et al., herbaria number MES-2001, CORDC00005551; 14 May 2016, Genbank acc. No. MT925622.

Argentina, Río Negro, Bariloche, Nahuel Huapi National Park, Los Rápidos. Associated with Nothofagus dombeyi and N. antarctica, leg. P. Brandon Matheny, herbaria number MES-1205; 11 May 2016, Genbank acc. No. MT925623.

Argentina, Río Negro, Bariloche, Nahuel Huapi National Park, Los Rápidos. Associated with Nothofagus antarctica, leg. Tuula Niskanen et al., herbaria number MES-1930, CORDC00005614; 13 May 2016.

Chile, Aysen, Carretera Austral, south of Bertrand port. Coordinates lat.: -47.0629 ; long.: -72.8008. Associated with managed Nothofagus pumilio and N. dombeyi forests, leg. C. Truong, herbaria number CT-4418, FLAS-F-63487; 03 May 2016, Genbank acc. No. MT925625.

Notes: Cortinarius egonii has a mean of $0 \mathrm{bp}$ within species variation in the ITS region, except for collection HCFC C80, that differs from the ITS sequence of the holotype by $0.7 \%$ (five substitutions and indels). C. egonii is the only representative of the UNITE SH1142013.08FU and differs by $4 \%$ (22 substitutions and indels) from the most closely related reference sequence C. rhodophyllus (GenBank Acc. No. KJ421051, Chile). The difference to all other species ranges between 4.5 and 9.0\% (29 and 50 substitutions and indels) ( $\mathrm{MW}=33, \mathrm{SD}=6)$. 
Cortinarius rhodophyllus was placed by Moser and Horak (1970) in subgenus Phlegmacium, section Calochroi. C. rhodophyllus clearly differs from C. egonii by having a bulbous stipe, reddish-salmon lamellae and amygdaliform spores. Morphologically, C. luteocaeruleus Moser somewhat resembles C. egonii. However, this species clearly differs from C. egonii by the bluish colors at the stipe apex, the red $\mathrm{KOH}$ reaction on the pileus, and distinctly larger basidiospores $(9.5-11 \times 6-6.7 \mu \mathrm{m})$. A sequence is not available for $C$. luteocaeruleus. Cortinarius punctatisporus Garnica morphologically also resembles C. egonii but differs with a clearly inflated stipe. Moreover, the ITS sequence similarity of $C$. egonii and C. punctatisporus is $<97 \%[8,38]$.

3.3.2. Cortinarius gracilentus Salgado Salomón and Peintner spp. nov.

MycoBank MB 836579

Etymology

The species epithet refers to the slender habitus of the basidiomata.

Diagnosis

Cortinarius gracilentus (B and D) is characterized by a glutinous, hygrophanous, cinnamon brown pileus, stipe cylindrical, dry, fibrous, white, with the remains of a caramel veil, and cocoa brown lamellae in young specimens. Basidiospores are elliptic, verrucose, 11.1 $\pm 0.7 \times 7.1 \pm 0.5 \mu \mathrm{m}$. Basidia stain with cotton blue and usually grow alone.

Type

Argentina, Chubut, Futaleufú, Los Alerces National Park, Río Rivadavia, Coordinates Lat.: -42.4002; Long.: -71.4081; Alt.: 502.1. Associated with Nothofagus dombeyi, leg. et det. María Eugenia Salgado Salomón, Holotype HCFC C66; Isotype: IB20170234, 18 April 2017, Genbank acc. No. MN707572.

\section{Macrocharacters}

PILEUS (1.9) 2.3-3.3 cm diam., convex to campanulate, becoming low convex with age. The margin of the pileus is plane. Pileus surface glutinous, hygrophanous, smooth. Pileus color varies between cinnamon (12A5 to 12E7) at the margins and amber brown (12L12 to 13K12) at discal zone.

LAMELLAE sinuate, subdistant, about 6-9 lamellae per $\mathrm{cm}$ at the pileus margin, margin finely eroded, color like milky tea (11B7 to 11C6), becoming amber brown (13K12).

STIPE (4.5) 4.8-7.8 (8.4) $\times 0.5 \mathrm{~cm}$, cylindrical to weakly clavate, dry, cartilaginous, whitish (9A1), with the remains of a caramel-colored universal veil (12F10) especially in the middle part; Cortina white silky in young specimens, evanescent. Brown rhizomorphs present.

CONTEXT (flesh) firm, corky with pale colors. Smells inconspicuous, slightly of fungi. Usually grow as single fruiting bodies. Macrochemical reactions; $20 \% \mathrm{KOH}$ on exsiccate slightly yellowish. No fluorescence was detected at $350 \mathrm{~nm}$ nor at $254 \mathrm{~nm}$ (in dry material).

Microcharacters

Basidiospores (9.1) 10.4-11.8 (13.8) × (5.3) 6.6-7.6 (8.7) $\mu \mathrm{m}$ (mean \pm sd: $11.1 \pm 0.7$ $\times 7.1 \pm 0.5 \mu \mathrm{m})$, Q: (1.2) $1.6 \pm 0.1(2) ;(n=131)$ for the holotype elliptical, verrucose, not dextrinoid, cocoa brown to coffee brown.

BASIDIA with four sterigmata and a basal clamp, clavate, (37)39-44(47) $\times(10) 11$ 12(13) $\mu \mathrm{m}(n=28)$, sterigmata $5-7(8) \mu \mathrm{m}$ long $(n=49)$, cyanophilous with cotton blue.

CYSTIDIA not observed.

LAMELLAR TRAMA consisting of parallel hyaline thin-walled hyphae with clamp connections and a diam. of 5-7 (8) $\mu \mathrm{m}(n=35)$.

PILEIPELLIS with a $200 \mu \mathrm{m}$ thick gelatinous layer of pileus context consisting of clamped hyaline hyphae with a diam. of $4-6(8) \mu \mathrm{m}(n=35)$, hyphae stain with $3 \% \mathrm{KOH}$ with yellowish colors (10I6 to 10J6). 
PILEUS CONTEXT $800-900 \mu \mathrm{m}$ wide, formed by two layers, the uppermost with inflated hyphae elements with a diam. Of (11) 15-31 (45) $\mu \mathrm{m}(n=37)$, spongy looking, hyaline, colorless, thin-walled, hyphal walls not encrusted. The intermediate layer has hyphae of a diam. of (8) 9-12 (15) $\mu \mathrm{m}(n=30)$, hyaline, colorless, thin-walled, hyphal walls not encrusted. None of the two layers are staining with $3 \% \mathrm{KOH}$, cotton blue, Melzer's reagent or Sulpho-vanillin. Within the regular layer of the context, there are non-clamped oleiferous-like hyphae of amber colors (1016 to 10J6; in 3\% KOH) they are thick-walled and somewhat irregular with a diam. of (3) 4-6 (7) $\mu \mathrm{m}(n=16)$. They do not stain with cotton blue, Melzer's reagent or Sulpho-vanillin.

Clamp connections present in all tissues.

Ecology and Distribution

Forest type-Nothofagus dombeyi and N. antarctica; observed in April. The monthly average temperature in the area is $8.9^{\circ} \mathrm{C}\left(\max / \min 13.7 / 2{ }^{\circ} \mathrm{C}\right)$, with a total of $82 \mathrm{~mm}$ precipitation in April (weather station Lago Cholila, data from 2017). Soil pH $=5.8$.

Other material examined: Argentina, Chubut, Futaleufú, Los Alerces National Park, Camping trail, coordinates Lat.: -42.4001; Long.: -71.4087; Alt.: 521.5 m.a.s.l., associated with Nothofagus antarctica, leg. et det. María Eugenia Salgado Salomón. Herbaria number HCFCC171, IB 20170235, 18 April 2017. Genbank acc. No. MN707580.

Notes: Cortinarius gracilentus has no within species ITS differences and differs by $0.1 \%$ (one substitution or indel) from the included subclade (MES-1597, MES-1801). The most closely related species is C. avellaneus Moser, which differs by $4.5 \%$ in the ITS region (23 substitutions or indels). The difference to all other species ranges from 4.5 to $9 \%$ (23-49 substitutions or indels MW $31+-8 \mathrm{bp}$ ).

Based on ITS sequences only, where the majority of reference sequences are available, C. gracilentus is closely related to $C$. avellaneus. Morphological characters confirm this relationship: C. avellaneus has darker avellaneous to umber brow dry pilei, yellow-rusty brown lamellae and further differs by ellipsoid to amygdaliform, strongly verrucose spores with an inconspicuous plage. The second species belonging to this stirps Avellaneus, $C$. fulvoconicus Moser, differs by the vividly red-brown pileus colours, the dry pileus, and narrower spores. Moser and Horak (1977) stated that stirps Avellaneus is closely related to stirps Rufus as confirmed by the sister group relationship to C. rufus Moser and C. subrufus San-Fabian, Niskanen \& Liimat. The stirps Rufus has been validated as sect. Austroamericani (San Fabian et al. 2018).

3.3.3. Cortinarius neuquensis Salgado Salomón, Peintner, Liimat. and Niskanen spp. nov. MycoBank MB 836823

Etymology

Epithet refers to Neuquén province (Argentina), where the first vouchers used for this species description were collected.

Diagnosis

Cortinarius neuquensis (E and A) has medium-sized basidiomata ( $3.5-5 \mathrm{~cm}$ pileus diam.) and is characterized by a light ochre brown to reddish brown, glutinous, not hygrophanous pileus, and a white, cylindrical, fragile, and dry stipe. The lamellae are pale argillaceous, with an entire margin and sinuate. Basidiospores are amygdaliform to elliptical and finely verrucose, (6.3) 7.3-8.3 (9.7) × (3.1) 3.6-4.1 (5.3) $\mu \mathrm{m}$. Basidia stain with cotton blue. In the external layer of context there are thick-walled hyphae that stain in cotton blue and do not have clamp connections.

Type

Argentina, Neuquén, Aluminé, Chañy Natural Protected Area, Arroyo Chañy, Coordinates Lat.: -38.9456; Long.: -71.3139; Alt.: 1165.5, in mixed forests of Nothofagus antarctica 
and Araucaria araucana, leg. et det. María Eugenia Salgado Salomón, Holotype: HCFC C206; Isotype: IB 20170222, 04 May 2017, Genbank acc. No. MN707582.

\section{Macrocharacters}

PILEUS 3.6-5.0 cm in diam., low convex, occasionally conical in young specimens, pileus margin somewhat wavy with age. Pileus surface glutinous, not hygrophanous, smooth. Pileus color varies between light ochre (10C1), golden light brown (10H4) to reddish brown, becoming with age honey ochre (12J6). The margin of the pileus is straight, and in young specimens slightly bent.

LAMELLAE sinuate, on average dense, about 12-14 lamellae per $\mathrm{cm}$ at the pileus margin, margin entire, pale argillaceus (9E4) to argillaceus (9E7), later cinnamon brass colored (11L6-11L9).

STIPE 3.5-7.5 $\times 0.7-1.1 \mathrm{~cm}$, cylindrical to somewhat rooting, corky, fragile, dry, white (9G1-9H1), with remnants of a pale cinnamon universal veil, especially in the middle part. Cortina white, quickly evanescent, when present, sparse, brown-ferruginous from the spore deposit (12L9).

Smell in lamellae, strong, spicy, sometimes slightly ammoniacal. Tastes mild. Usually grows alone.

Macrochermical reactions; $20 \% \mathrm{KOH}$, negative on dry basidiomes. No fluorescence was detected at $350 \mathrm{~nm}$ nor at $254 \mathrm{~nm}$ (in exsiccate material).

Microcharacters

Basidiospores (6.3) 7.3-8.3 (9.7) × (3.1) 3.6-4.1 (5.3) $\mu \mathrm{m}$ (mean \pm sd: $7.8 \pm 0.5 \times 3.9 \pm$ $0.3 \mu \mathrm{m}$, Q: (1.4) $2 \pm 0.2(2.4) ;(n=125)$ for holotype (measured from the stipe or cortina), pale golden brown, amygdaliform to elliptical, finely verrucose, not dextrinoid.

BASIDIA with four sterigmata and a basal clamp, clavate, (23) 24-30 (33) $\times 6-7 \mu \mathrm{m}$, sterigmata 2-4 (5) $\mu \mathrm{m}$ long $(n=16)$, cyanophilous with cotton blue. Does not stain with $\mathrm{KOH}$ nor Sulpho vanillin.

CYSTIDIA not observed.

LAMELLAR TRAMA consisting of parallel thin-walled hyaline hyphae with a diam. of (6) 7-11 (15) $\mu \mathrm{m}(n=31)$.

PILEIPELLIS a cutis of regular, slightly interwoven hyphae, approximately $170 \mu \mathrm{m}$ thick, uppermost layer gelatinous, hyphae hyaline, with a diam. of 2-3 (5) $\mu \mathrm{m}(n=20)$.

PILEUS CONTEXT consisting of two layers. External layer with regular hyphae elements with a diam. of (8) 11-19 (25) $\mu \mathrm{m}(n=22)$ hyaline, colorless, thin-walled, hyphal walls not encrusted, not staining with $3 \% \mathrm{KOH}$, cotton blue, Melzer's reagent or Sulphovanillin, approximately $450 \mu \mathrm{m}$ thick. Internal layer with globose hyphae elements, diam. of (22) 25-36 (46) $\mu \mathrm{m}(n=20)$ hyaline, colorless, thin-walled, hyphal walls not encrusted, not staining with $3 \% \mathrm{KOH}$, cotton blue, Melzer's reagent or Sulpho-vanillin, approximately $250 \mu \mathrm{m}$ thick. In the external layer oleiferous-like unclamped thick-walled hyphae with a diam. of (3) $4-5 \mu \mathrm{m}(n=10)$ are present. These hyphae run longitudinal to context, and are cyanophilous, but do not stain with Melzer's reagent or Sulpho-vanillin.

Clamp connections present in all tissues.

Ecology and Distribution

Forest type-mostly in forest of Nothofagus antarctica, but also in forests of N. dombeyi and in mixed forests of Lophozonia alpina-L. obliqua; observed during May. The monthly average in May temperature in the area is $9{ }^{\circ} \mathrm{C}\left(\max / \mathrm{min} 14 / 6^{\circ} \mathrm{C}\right)$, with a total of $88 \mathrm{~mm}$ precipitation (weather station Lago Norquinco, data from 2017). Soil $\mathrm{pH}=6.1$. This species has also been detected in Chile (KY462703, KY462509)

Other material examined: Argentina, Neuquén, Aluminé, Lanín National Park, Norquinco Lake, coordinates Lat.: -39.0877; Long.: -71.1546; Alt.: 1060.1 m.a.s.l., associated with mixed forest of Lophozonia alpina and L. obliqua, leg. et det. María Eugenia Salgado Salomón. Herbaria number HCFCC196, IB 20170218, 3 May 2017. Genbank acc. No. MN707581. 
Argentina, Neuquén, Aluminé, Chañy Natural Protected Area, Chañy stream, Coordinates Lat.: -38.9456; Long.: -71.3139; Alt.: 1165.5. associated with mixed forests of Nothofagus antarctica and Araucaria araucana, leg. et det. María Eugenia Salgado Salomón, herbaria number HCFC C210, IB 20170222, 4 May 2017, Genbank acc. No. MN707583.

Chile, Osorno, Puyehue National Park, foothills of Volcan Puyehue, up the road past el Caulle north of Río Golgol, associated with Nothofagus dombeyi, leg. Tuula Niskanen et al., herbaria number MES-1638, 234,303 (k), FLAS-F-64429; 4 May 2016, Genbank acc. No. KY462509.

Argentina, Río Negro, Bariloche, Nahuel Huapi National Park, road to tronador, at the end of lake Muscardi before Pampa Linda. Associated with Nothofagus antarctica, leg. Tuula Niskanen et al., herbaria number MES-2009, CORDC00005547; 14 May 2016, Genbank acc. No. MT925951.

Argentina, Río Negro Bariloche, Nahuel Huapi National Park, along road halfway to Tronador. Associated with Nothofagus antarctica, leg. Brandon Matheny, herbaria number MES-1148, CORDC00005190; 9 May 2015, Genbank acc. No. MT925952.

Chile, Osorno, Puyehue National Park, near Aguas Calientes inside the national park. Associated with Nothofagus dombeyi, leg. Tuula Niskanen et al., herbaria number MES-1551, K(M)234248, FLAS-F-64363; 3 May 2016, Genbank acc. No. MT925953.

Notes: Cortinarius neuquensis has a mean within species ITS difference of $0-0.7 \%$ (0-4 substitutions and indels) and differs by $2-3 \%$ (12-17 substitutions and indels) from C. verniciorum Soop, and by $2.5 \%$ (14-15 substitutions and indels) from C. perelegans Soop. The difference from all other species ranges $5-8 \%$ (29-50 substitutions and indels, $\mathrm{MW}=32$, $\mathrm{SD}=6$ ). Cortinarius verniciorum and C. ducamarus Soop from New Zealand belong to the same section Verniciori Soop. These two species differ by orange brown basidiomes with strongly viscid pilei. Cortinarius viscovenetus Horak is morphologically similar. However, the spores are significantly larger $(10-11 \times 6.8-7.2 \mu \mathrm{m})$. The ITS sequence similarity of these two species is $<97 \%$ (unpublished).

3.3.4. Cortinarius pseudoxiphidipus Salgado Salomón and Peintner spp. nov.

MycoBank MB 836577

Etymology

The epithet refers to its morphological affinity to Cortinarius xiphidipus.

Diagnosis

Cortinarius pseudoxiphidipus (A and B) is characterized by glutinous, hygrophanous, honey brown pileus, subclavately radicant, dry, fibrous, whitish stipe with pale copper veil remaining and concolorous, copper-colored lamellae in young specimens. Basidiospores are elliptical, finely verrucose, $11.4 \pm 0.8 \times 5.6 \pm 0.3 \mu \mathrm{m}$, hymenial cystidia not present. Usually growing in scatted groups.

Type

Argentina, Chubut, Futaleufú, Los Alerces National Park, Río Rivadavia, Coordinates Lat.: -42.4003; Long.: -71.4107; Alt.: 511.7. Associated with Nothofagus dombeyi, leg. et det. María Eugenia Salgado Salomón, Holotype (CIEFAP) HCFCC88; Isotype (IB): IB 20170347, 19 April 2017, Genbank acc. No. MN707575.

Macrocharacters

PILEUS (2.2) 2.4-4.4 (5) cm diam., convex, becoming low convex with age. The margin of the pileus is slightly bent, in young specimens slightly involute, becoming alveolate, with deep indentations. Pileus surface glutinous, hygrophanous, smooth. Pileus color varies between honey brown (11K6 to 11K5, Rattan) to amber brown (13K12 to 13J12) in discal zone. 
LAMELLAE sinuate, on average dense, about 12-14 lamellae per $\mathrm{cm}$. at the pileus margin, margin finely eroded, with copper colors (11L6, brass), later with wild honey colors (13L9).

STIPE (3.1) 4-5.8 (6.6) × 0.7-1.3 (1.8) cm, radicant to weakly cylindrical, bent, dry, fibrous, whitish (10A1), with remnants of pale copper veil, especially in the middle part. Cortina white silky in young specimens, evanescent.

CONTEXT (flesh) firm, corky with pale colors. Smells slightly fruity. Tastes mild.

Usually growing in scattered small groups.

Macrochemical reactions; $20 \% \mathrm{KOH}$ on exsiccate material slightly yellowish. Yellowish reaction on exsiccate lamella with $3 \% \mathrm{KOH}$. No fluorescence was detected at $350 \mathrm{~nm}$ nor at $254 \mathrm{~nm}$ (in exsiccate material).

Microcharacters

Basidiospores (9.1) 10.6-12.2 (13.5) × (4.5) 5.3-6 (6.7) $\mu \mathrm{m}$ (mean $\pm \mathrm{sd}: 11.4 \pm 0.8 \times 5.6$ $\pm 0.3 \mu \mathrm{m}), \mathrm{Q}:(1.6) 2 \pm 0.1(2.6) ;(n=159)$ amygdaliform to sublimoniform, finely verrucose, not dextrinoid, golden brown to cocoa brown (for holotype, measured from the stipe or cortina). Basidiospores on lamellae heterogeneous in size when immature usually smaller and paler than mature basidiospores.

BASIDIA with four sterigmata and a basal clamp, clavate, (34) 36-40 (41) × 9-11 (12) $\mu \mathrm{m}$, sterigmata 4-6 $\mu \mathrm{m}$ long $(n=10)$. Some basidia with oily yellow content when observed in $\mathrm{KOH}(3 \%)$. Does not stain with cotton Blue, Melzer's reagent or Sulpho vanillin.

CYSTIDIA not observed.

LAMELLAR TRAMA consisting of parallel hyaline thin-walled hyphae with clamp connections and a diam. of (2) 4-5(6) $\mu \mathrm{m}(n=30)$.

PILEIPELLIS with a gelatinous layer, pileus context consisting of clamped hyaline hyphae with a diam. of 4-6 (7) $\mu \mathrm{m}(n=14)$.

PILEUS CONTEXT 350 to $400 \mu \mathrm{m}$ wide, formed by two layers, The uppermost with regular hyphae elements with a diam. Of (12) 13-19 (23) $\mu \mathrm{m}(n=15)$ hyaline, colorless, thinwalled, hyphal walls not encrusted. The intermediate layer has inflated hyphae elements with a diam. of (32) 34-39 (40) $\mu \mathrm{m}(n=10)$ hyaline, colorless, thin-walled, hyphal walls not encrusted. None of layers are staining with $3 \% \mathrm{KOH}$, cotton blue, Melzer's reagent or Sulpho vanillin. Clamp connections present in all tissues.

Ecology and Distribution

Forest type-Nothofagus dombeyi; observed in April. The monthly average temperature in the area is $8.9^{\circ} \mathrm{C}\left(\mathrm{max} / \mathrm{min} 13.7 / 2{ }^{\circ} \mathrm{C}\right)$, with a total of $82 \mathrm{~mm}$ precipitation in April (weather station Lago Cholila, data from 2017). Soil $\mathrm{pH}=5.8$.

Other material examined: Argentina, Chubut, Futaleufú, Los Alerces National Park, Río Rivadavia trail, coordinates Lat.: -42.4002; Long.: -71.4108; Alt.: $502.1 \mathrm{~m}$ a.s.1., associated with Nothofagus dombeyi, leg. et det. María Eugenia Salgado Salomón. Herbaria number HCFCC78, IB 20170340, 18.04.2017. Genbank acc. No. MN707573.

Argentina, Chubut, Futaleufú, Los Alerces National Park, Río Rivadavia trail, coordinates Lat.: -42.4003; Long.: -71.4107; Alt.: 511.7 m.a.s.1., associated with Nothofagus dombeyi, leg. et det. María Eugenia Salgado Salomón. Herbaria number HCFCC90, IB 20170441, 18.04.2017. Genbank acc. No. MN707576.

Notes: Cortinarius pseudoxiphidipus has a mean within species ITS difference of $0 \mathrm{bp}$ and differs by $>5 \%$ (28-48 substitution and indels MW $29 \pm 4$ bp) from the other species included in the phylogeny, and the difference to $C$. xiphidipus, which it resembles morphologically, is $>6 \%$. Cortinarius pseudoxiphidipus has smaller basidiomes, lamellae with copper colors, and larger basidiospores than C. xiphidipus. Cortinarius xiphidipus has argillaceous lamellae, and elliptical, finely warty spores of $6-8 \times 4-4.8 \mu \mathrm{m}$. 
3.3.5. Cortinarius voluptatis Salgado Salomón and Peintner spp. nov.

MycoBank MB 836578

Etymology

From Latin, the one who provides pleasure or joy. The species epithet refers to the red wine colors of the pileus in young specimens.

Diagnosis

Cortinarius voluptatis (C and E) is characterized by glutinous, red wine pileus, subclavate, dry, fibrous, whitish stipe with remaining of red-violaceus veil and lilaceous lamellae in young specimens. Basidiospores elliptic, verrucose, $13.1 \pm 0.7 \times 8.0 \pm 0.5 \mu \mathrm{m}$, subclavate cheilocystidia present. Usually growing in small groups.

Type

Argentina, Neuquén, Lácar, San Martín de los Andes, Lanín National Park, Yuco, Coordinates Lat.: -40.09974; Long.: -71.31527; Alt.: 657.5. Associated with Lophozonia alpina and L. obliqua, leg. et det. María Eugenia Salgado Salomón, Holotype (CIEFAP) HCFCC219; Isotype (IB): IB 20170231, 5 May 2017, Genbank acc. No. MN707585.

\section{Macrocharacters}

PILEUS (4.3) 4.8-6.4 (6.7) cm diam., convex when young, becoming applanate with age. The margin of the pileus is slightly bent, in young specimens slightly involute, becoming undulate. Pileus surface glutinous, hygrophanous, smooth. Pileus color varies between red wine (7J6 to 7L10, Spanish wine), later with Hazel colors (12I7 to 13J9, Hazel) and more vivid, gold-brown color in the discal zone (14F12).

LAMELLAE sinuate, on average dense, about 12-14 lamellae per $\mathrm{cm}$ at the pileus margin, margin finely eroded, light violaceous (54A5 to 55A5, La Valière), becoming light brown (13A6).

STIPE (6.2) 6.8-8.2 (8.5) $\times$ 0.7-1.3 (1.4) cm, subclavate to cylindrical, dry, fibrous, whitish (10A1), with the remains of a red-violaceus veil, especially in the middle part which gives the whole stipe a lilac hue when young, white cortina, silky in young specimens, evanescent.

PILEUS CONTEXT (flesh) firm, cartilaginous with pale colors. Smells sweetish ammoniacal. Taste not detected.

Usually growing in scattered small groups.

Macrochemical reactions; $20 \% \mathrm{KOH}$ on exsiccate. Pileus slightly yellowish. No fluorescence was detected at $350 \mathrm{~nm}$ nor at $254 \mathrm{~nm}$ (in exsiccate material).

\section{Microcharacters}

Basidiospores (11.6) 12.4-13.7 (15.9) × (6.5) 7.5-8.5 (9.8) $\mu \mathrm{m}$ (mean \pm sd: $13.1 \pm 0.7$ $\times 8 \pm 0.5 \mu \mathrm{m}), \mathrm{Q}:(1.3) 1.6 \pm 0.1(2) ;(n=141)$ for holotype (measured from the stipe or cortina) Elliptical to subamygdaliform, clearly verrucose, without plage, not dextrinoid, coffee to cocoa brown. Basidiospores on lamellae heterogeneous in size, when immature usually smaller and paler than mature basidiospores.

BASIDIA with four sterigmata and basal clamp, clavate, (33) 34-38 × 9-12 (13) $\mu \mathrm{m}$, sterigmata 3-5 $\mu \mathrm{m}$ long $(n=10)$.

CHEILOCYSTIDIA present, slightly clavate, 34-39 $(40) \times 10-12 \mu \mathrm{m}(n=10)$, scarce.

LAMELLAR TRAMA consisting of parallel hyaline thin-walled hyphae with clamp connections and a diam. Of (4) 6-10 (12) $\mu \mathrm{m}(n=32)$.

PILEIPELLIS with a $270 \mu \mathrm{m}$ wide gelatinous layer of consisting of clamped hyaline hyphae with a diam. Of (4) 5-6 (7) $\mu \mathrm{m}(n=40)$.

CONTEXT $650 \mu \mathrm{m}$ approx. wide, with inflated hyphae elements, hyaline, colorless, thin-walled, hyphal walls not encrusted with a diam. Of (17)18-40 $\mu \mathrm{m}(n=10)$, the first $130 \mu \mathrm{m}$ of context staining yellowish with $3 \% \mathrm{KOH}$. This layer amber in color (1016 to 10J6; in $3 \% \mathrm{KOH}$ ); thick-walled, irregular, no clamped oleiferous-like hyphae with a diam. Of 
5-8 (10) $\mu \mathrm{m}(n=11)$. No elements of the context are staining with cotton blue, Melzer's reagent or Sulpho vanillin.

Clamp connections present in all tissues.

Ecology and Distribution

Forest type-Lophozonia alpina and L. obliqua but occasionally with $N$. antarctica; observed in May. The monthly average temperature in the area is $7^{\circ} \mathrm{C}\left(\max / \mathrm{min} 12 / 2{ }^{\circ} \mathrm{C}\right)$, with a total of $136 \mathrm{~mm}$ precipitation in May (weather station Chapelco Aero, data from 2017). Soil $\mathrm{pH}=5.8$.

Other material examined: Argentina, Chubut, Futaleufú, Los Alerces National Park, Rivadavia Camping area, coordinates Lat.: -42.4006, Long.: -71.4073; Alt.: 506.8 m.a.s.1. Associated with Nothofagus antarctica, leg. et det. María Eugenia Salgado Salomón, CIEFAP herbarium HCFCC157; IB 20170109, 25 April 2017, Genbank acc. No. MN707579.

Argentina, Neuquén, Lácar, San Martín de los Andes, Lanín National Park, Yuco, coordinates Lat.: -40.0997, Long.: -71.3154, Alt.: 657.5 m.a.s.1. Associated with Lophozonia alpina and L. obliqua, leg. et det. María Eugenia Salgado Salomón, CIEFAP herbarium HCFCC218; IB 20170229, 5 May 2017, Genbank acc. No. MN707584.

Argentina, Neuquén, Lácar, San Martín de los Andes, Lanín National Park, Yuco, coordinates Lat.: -40.0989, Long.: -71.3147, Alt.: 653.6 m.a.s.1. Associated with Lophozonia alpina and L. obliqua, leg. et det. María Eugenia Salgado Salomón, CIEFAP herbarium HCFCC230; IB 20170238, 5 May 2017, Genbank acc. No. MN707587.

Notes: Cortinarius voluptatis has a mean within species ITS difference of $0.1 \%$ (one substitution or indel) and differs by $2.3 \%$ (13 substitutions or indels) from the most closely related species $C$. cinereus Moser. The difference to all other species ranges between 3 and $9 \%$ (17 and 49 substitutions or indels $\mathrm{MW}=27, \mathrm{SD}=7$ ).

Based on morphology, C. voluptatis could belong to Section Myxotelamonia Subsect. Lilacifolii [5]. The type of the section, C. roseopurpurascens Moser \& Horak, somewhat resembles $C$. voluptatis, but differs by the stipe being lilaceous, it has significantly smaller spores $(10-12.5 \times 6.5-7.5 \mu \mathrm{m})$ and it lacks a veil. Moser \& Horak [5] hypothesized that this section could represent an endemic South American complex of species without morphologically similar species in the Northern Hemisphere. Old specimens of Cortinarius voluptatis could be confused with C. pseudoxiphidipus because of the size and fruiting habit, but $C$. voluptatis can be differentiated by the darker color of the veil and the larger spores. Cortinarius juglandaceus Soop resembles C. voluptatis but is not closely related. C. juglandaceus is viscid whereas $C$. voluptatis has a glutinous pileus surface and has larger spores [54]. Cortinarius juglandaceus occurs in Nothofagus forests in New Zealand.

\section{Discussion}

Five new species of Cortinarius are proposed here based on morphological and molecular data. Cortinarius is an ectomycorrhizal genus [55] and it is possible that associations with specific host tree species help to explain high regionalism and habitat relationship. Several Cortinarius species described from Patagonia are thought to associate only with a specific Nothofagaceae host tree species, including, C. magellanicus Speg., C. horakii Valenz. \& EsteveRav., C. magellanicoalbus Salgado Salomón \& Peintner, C. austronanceiensis (Moser) Garnier, C. capitellinus Horak, C. cinereus Moser, C. brachyspermus Peintner \& Moser, C. glutinopallens (Horak) Peintner \& Moser, C. cretaceus (Horak) Horak and C. roblerauli Salgado Salomón \& Peintner [1]. Due to undersampling and the difficult taxonomy of Cortinarius in Patagonia, it is possible that specific host associations could be more frequent than previously assumed. The newly described C. pseudoxiphidipus could represent one of these species with strong host preferences or host specificity since it was found only associated with N. dombeyi. Similarly, C. egonii and C. gracilentus showed specificity at the genus level and were only found with Nothofagus species. Within the genus Cortinarius there are also several ectomycorrhizal species with more generalist plant host associations, such as C. albocanus (Horak \& Moser) Peintner \& Moser, C amoenus (Moser \& Horak) Garnier, C. austroduracinus 
Moser, C. austrosalor Moser, C. collariatus Horak \& Moser and C. flammuloides Horak \& Moser. They are all reportedly associated with Nothofagaceae species present in Patagonia [1]. We observed the same generalist pattern for $C$. voluptatis and C. neuquensis, which are associated with both Lophozonia and Nothofagus spp.

The phylogenetic placement of the five new species proposed in this work into subsections, sections, or even subgenera was not possible due to limited phylogenetic resolution and the lack of closely related reference taxa. The combined phylogenetic analysis of ITS, LSU and RPB1 resulted in a well-supported clade consisting of C. pseudoxiphidipus, C. voluptatis and C. egonii. They all have a similar habitus. However, we are reluctant to define new, possibly endemic South American sections of Cortinarius based only on three species. The lack of reference data shows that the South American Cortinarius diversity is still widely underexplored and it also suggests the presence of endemic Cortinarius lineages in this area. Up until now there is very little overlap between Cortinarius species described from Australia and New-Zealand [38] with the species reported from South American Nothofagaceae forests. Given the high diversity of Southern Hemisphere Cortinarius diversity and the lack of available reference sequences, it is not surprising that the phylogeny of Cortinarius species remains largely unresolved. Based on available data it seems likely that that endemic South American Cortinarius lineages exist. The recently proposed Cortinarius section Austramericani [16] (p. 1130) could be an example for such an endemic lineage of Patagonian Cortinarius species associated with Nothofagus species. More intense investigations on the diversity of this genus in South America are urgently needed, as this will not only clarify the Patagonian Cortinarius diversity, but will also provide fascinating insights into the evolution of ectomycorrhizal associations on a global scale.

"Southern Gondwana" connections are often explained by the presence of specific host plants in the Southern Hemisphere that are absent in other regions and vice versa [56-58]. Due to their association with Nothofagaceae forests, Southern Gondwanan connections could also be assumed for several lineages of Cortinarius, as already proposed for other genera of ectomycorrhizal fungi [59-62]. For example, the / Pseudotriumphans clade of Cortinarius is shared between South America and Oceania (Australia-Tasmania and New Zealand), and therefore very likely to represent a Southern Hemisphere lineage of Cortinarius with wide Nothofagaceae host range [24] (p. 1049) and [23] (p. 1467). However, at the moment the available data only allow for speculation. A better knowledge of fungal diversity is needed to understand the evolutionary history of ectomycorrhizal fungi in Patagonian forests.

The ITS region is frequently used for fungal species identification [37,63-66]. However, the ITS region has only minimal variation across Cortinarius and therefore probably underestimates the true diversity of this genus in natural ecosystems by up to $20 \%$ [67]. Barcoding is a powerful tool for ecological, environmental, or taxonomic research [68]. However, fungi occurring in the Southern Hemisphere are still largely under-represented in public databases [61], and data concerning their diversity and distribution are far from being complete, even when Cortinarius spp. are often quite dominant in studies of ectomycorrhizal fungi communities on roots and in soil $[1,13,61,68,69]$. This is especially true and important for fungal groups with immense species richness like Cortinarius, a widespread and important ectomycorrhizal genus from the South American Nothofagaceae forests with high ecological, forest restoration interests, and important non-timber forest products.

\section{Conclusions}

The diversity of Cortinarius from the Northern Hemisphere and from New-Zealand and Australia have been extensively studied (e.g., [24,38,68,70-72]). However, aside from the pioneering work from Moser and Horak $[5,26]$ there are relatively few studies that have focused on South American Cortinarius diversity [25]. Recent studies describing several new species or even new sections highlight this knowledge gap $[8,12,15,16,67]$. Based on our current knowledge, the Cortinarius species associated with Nothofagaceae species rarely or never occur outside the distribution range of their host trees [26,71-75], making it highly likely that, after losing the connection via Antarctica, endemic Cortinarius lineages evolved 
in South America and Australasia. Cortinarius harbors a high diversity in these habitats, including many taxa that are waiting to be discovered $[15,16]$. In the future, systematic approaches will be important to fully sample Cortinarius from South America. These approaches should include DNA barcording of South American Cortinarius herbarium and systematic sampling of Nothofagaceae forests by South American mycologists.

Supplementary Materials: The following are available online at https://www.mdpi.com/article/10 .3390 /life11050420/s1, Figure S1: Phylogenetic relationship (Bayesian consensus tree) of four new species of Cortinarius from South American Nothofagaceae forests, based on combined rDNA ITS-LSU and RPB1 sequences. Bayesian Posterior Probabilities are provided beside nodes. C. gracilentus was not included in the analysis. Sequences generated from the new species presented are highlighted in red.

Author Contributions: Conceptualization, U.P., C.B. and M.E.S.S.; methodology, M.E.S.S. and U.P.; software, U.P. and M.E.S.S.; validation, U.P., T.N., K.L. and M.E.S.; formal analysis, M.E.S.S. and U.P; investigation, M.E.S.S., C.B. and U.P.; resources, M.E.S.S., U.P., T.N. and M.E.S.; data curation, M.E.S.S., K.L. and T.N.; writing—original draft preparation, M.E.S.S.; writing—review and editing, M.E.S.S., C.B., U.P., T.N., K.L. and M.E.S.; visualization, M.E.S.S.; supervision, C.B. and U.P.; project administration, M.E.S.S. and U.P.; funding acquisition, U.P., M.E.S. and M.E.S.S. All authors have read and agreed to the published version of the manuscript.

Funding: This research was funded by Österreichische Akademie der Wissenschaften (JESH program), the Tiroler Wissenschaftsfonds Project number ZAP718017, Universidad Nacional de la Patagonia San Juan Bosco (FI_005/15 Project), US National Science Foundation (grant DEB 1354802 to ME Smith), the University of Florida Institute for Food and Agricultural Sciences (ME Smith) and Bentham-Moxon Trust (to T. Niskanen).

Institutional Review Board Statement: Not applicable.

Informed Consent Statement: Not applicable.

Data Availability Statement: Data is contained within the article or supplementary material.

Acknowledgments: We are grateful to Administración de Parques Nacionales, Patagonian Delegation, and Neuquén province government for allowing us work in Los Alerces, Lago Puelo, Lanín National Parks and Chañy Protected Area, respectively. Collecting permits were issued by Chilean Corporación Nacional Forestal (Gerencia de Areas SilvestresProtegidas) (no. 014/2014, M.E.S.) and the Wildlife Conservation Society Chile in Parque Karukinka (C. Truong). Thanks are due to Valeria Silva and Juan Monges for their kind help in field trips and Camille Truong and P. Brandon Matheny for collecting and documenting materials of C. egonii and C. neuquensis. Regina Kuhnert is warmly thanked for her help in the mycological collection IB/IBF, Alija Mujic for producing part of the ITS sequences of the MES collections and Philipp Dresch, Johannes Falbesoner as well as Felipe Galleguillos for their help in the lab in Innsbruck (Innsbruck University). Götz Palfner for his comments and picture. ME Smith thanks Giuliana Furci, Daniella Torres and Pablo Sandoval for critical logistical support during fieldwork in Chile and Eduardo Nouhra and Francisco Kuhar for support during fieldwork. MESS and CB are researchers for the National Research Council of Argentina (CONICET).

Conflicts of Interest: The authors declare no conflict of interest.

\section{References}

1. Barroetaveña, C.; Salgado Salomón, M.E.; Bassani, V. Rescuing the ectomycorrhizal biodiversity associated with South American Nothofagaceae forest, from the 19th century naturalists up to molecular biogeography. Forestry 2019, 92, 500-511. [CrossRef]

2. Bödeker, I.T.M.; Clemmensen, K.E.; de Boer, W.; Martin, F.; Olson, A.; Lindahl, B.D. Ectomycorrhizal Cortinarius species participate in enzymatic oxidation of humus in northern forest ecosystems. New Phytol. 2014, 203, 245-256. [CrossRef] [PubMed]

3. Arnold, N.; Palfner, G.; Schmidt, J.; Kuhnt, C.; Becerra, J. Chemistry of the aroma bouquet of the edible mushroom "lebre" (Cortinarius lebre, Basdiomycota, Agaricales) from Chile. J. Chil. Chem. Soc. 2012, 57, 1333-1335. [CrossRef]

4. Gamundí, I.J.; Horak, E. Hongos De Los Bosques Andino Patagónicos; Vázquez Mazzini Editores: Buenos Aires, Argentina, 1993.

5. Moser, M.; Horak, E. Cortinarius Fr. und nahe verwandte gattungen in südamerika. Nova Hedwig. Beih. 1975, 52, 1-628.

6. Toledo, C.V.; Barroetaveña, C.; Rajchenberg, M. Phenology and environmental variables associated to the fruiting of wild edible mushrooms from Andean-Patagonia forests in Argentina. Rev. Mex. Biodivers. 2014, 85, 1093-1103. [CrossRef] 
7. Toledo, C.V.; Barroetaveña, C.; Fernandes, A.; Barros, L.; Ferreira, I. Chemical and antioxidant properties of wild edible mushrooms from native Nothofagus spp. forest, argentina. Molecules 2016, 21, 1201. [CrossRef]

8. Garnica, S.; Weiß, M.; Oberwinkler, F. New Cortinarius species from Nothofagus forests in South Chile. Mycologia 2002, 94, 136-145. [CrossRef]

9. Garrido, N.N. Agaricales s. 1. und ihre Mykorrhizen in den Nothofagus- Waldern Mittelchiles. In Bibliotheca Mycologica: Band 120; J. Cramer: Berlin/Stuttgart, Germany, 1988.

10. Horak, E.; Moser, M. Fungi austroamericani. 12. Studien zur Gattung Thaxterogaster Singer R. Nova Hedwig. 1965, 10, $211-242$.

11. Horak, E. Flora criptogámica de Tierra del Fuego. Orden Agaricales; Tomo 11: Buenos Aires, Argentina, $1979 ;$ pp. 1-524.

12. Liimatainen, K.; Niskanen, T.; San-Fabian, B.; Mujic, A.B.; Peintner, U.; Dresch, P.; Furci, G.; Nouhra, E.; Matheny, P.B.; Smith, M.E. Cortinarius section Thaumasti in South American Nothofagaceae forests. Mycologia 2020, 112, 329-341. [CrossRef]

13. Nouhra, E.; Urcelay, C.; Longo, S.; Tedersoo, L. Ectomycorrhizal fungal communities associated to Nothofagus species in Northern Patagonia. Mycorrhiza 2013, 23, 487-496. [CrossRef]

14. Salgado Salomón, M.E.; Dresch, P.; Horak, E.; Galleguillos, F.; Barroetaveña, C.; Peintner, U. The enigmatic Cortinarius magellanicus complex occurring in Nothofagaceae forests of the Southern Hemisphere. Fun. Biol. 2018, 22, 1077-1097. [CrossRef]

15. San Fabian, B.; Niskanen, T.; Liimatainen, K.; Kooij, P.W.; Mujic, A.B.; Truong, C.; Peintner, U.; Dresch, P.; Nouhra, E.; Matheny, P.B.; et al. New species of Cortinarius sect. Austroamericani, sect. nov., from South American Nothofagaceae forests. Mycologia 2018, 11, 1127-1144. [CrossRef]

16. Singer, R. The agaric of the argentine sector of Tierra del Fuego and limitrophous regions of the Magallanes area. Part I. White and pink species groups. Sydowia 1952, 6, 165-226.

17. Singer, R. Forest mycology and forest communities in South America II: Mycorrhiza sociology and fungus succession in the Nothofagus dombeyi-Austrocedrus chilensis woods of Patagonia. In Mycorrhizae; Hacskaylo, R., Ed.; USDA Forest Service, Miscellaneous Publication: Washington, DC, USA, 1971; Volume 1189, pp. 204-215.

18. Singer, R.; Moser, R. Forest mycology and forest communities in South America. Mycopathol. Mycol. Appl. 1965, 26, 130-191. [CrossRef]

19. Spegazzini, C. Fungi patagonici. Boletín Acad. Nac. Cienc. Córdoba 1887, 21, 5-64.

20. Spegazzini, C. Fungi fuegiani. Boletín Acad. Nac. Cienc. Córdoba 1887, 21, 135-308.

21. Valenzuela Flores, E. Estudio Sistemático Corológico y Ecológico de los Agaricales Sensu Lato de los Bosques Autóctonos de la Región de los Lagos en Chile. Ph.D. Thesis, Sección Biológicas, Departamento de Biología Vegetal, Facultad de Ciencias, Universidad de Alcalá de Henares, Alcalá de Henares, Madrid, España, 1993.

22. Garnica, S.; Weiß, M.; Oertel, B.; Oberwinkler, F. A framework for a phylogenetic classification in the genus Cortinarius (Basidiomycota, Agaricales) derived from morphological and molecular data. Can. J. Bot. 2005, 83, 1457-1477. [CrossRef]

23. Peintner, U.; Moncalvo, J.M.; Vilgalys, R. Toward a better understanding of the infrageneric relationships in Cortinarius (Agaricales, Basidiomycota). Mycologia 2004, 96, 1042-1058. [CrossRef]

24. Garnica, S.; Weiß, M.; Oberwinkler, F. Morphological and molecular phylogenetic studies in South American Cortinarius species. Mycol. Res. 2003, 107, 1143-1156. [CrossRef] [PubMed]

25. Horak, E. Fungi Austroamericani IV. Revisión de los hongos superiores de Tierra del Fuego, Patagonia en el Herbario de C. Spegazzini en La Plata. Darwiniana 1967, 14, 355-385.

26. Horak, E.; Wood, A.E. Cortinarius Fr. (Agaricales) in Australasia. 1. Subgen. Myxacium and subgenus Paramyxacium. Sydowia 1990, 42, 88-168.

27. Palfner, G. Taxonomische Studien an Ektomykorrhizen aus den Nothofagus—Wäldern Mittelsüdchiles. Bibl. Mycol. 2001, 190, $1-243$.

28. Segedin, B.; Pennycook, S. A nomenclatural checklist of agarics, boletes, and related secotioid and gasteromycetous fungi recorded from New Zealand. N. Z. J. Bot. 2001, 39, 285-348. [CrossRef]

29. Frøslev, T.G.; Jeppesen, T.S.; Læssøe, T. Seven new calochroid and fulvoid species of Cortinarius. Mycol. Res. 2006, 110, 1148-1160. [CrossRef]

30. Garnica, S.; Weiß, M.; Oertel, B.; Ammirati, J.; Oberwinkler, F. Phylogenetic relationships in Cortinarius, section Calochroi, inferred from nuclear DNA sequences. BMC Evol. Biol. 2009, 9. [CrossRef] [PubMed]

31. Moser, M.; Peintner, U. Die phylogenetischen Beziehungen der Cortinarius aureopluverulentus Gruppe. Micol. Veget. Medit. 2002, 17, 3-17.

32. Niskanen, T.; Liimatainen, K.; Mahiques, R.; Ballarà, J.; Kytövuori, I. Cortinarius badiolaevis, a new conifer-associated, darkening species in the subgenus Telamonia (Basidiomycota, Agaricales). Mycol. Prog. 2011, 10, 101-105. [CrossRef]

33. Niskanen, T.; Liimatainen, K.; Ammirati, J.F.; Hughes, K. Cortinarius section Sanguinei in North America. Mycologia 2013, 105, 344-356. [CrossRef] [PubMed]

34. Niskanen, T.; Liimatainen, K.; Ammirati, J.F. Five new Telamonia species (Cortinarius, Agaricales) from western North America. Botany 2013, 91, 478-485. [CrossRef]

35. Peintner, U.; Horak, E.; Moser, M.; Vilgalys, R. Phylogeny of Rozites, Cuphocybe and Rapacea inferred from ITS and LSU rDNA sequences. Mycologia 2002, 94, 620-629. [CrossRef] [PubMed] 
36. Peintner, U.; Moser, M.M.; Thomas, K.A.; Manimohan, P. First records of ectomycorrhizal Cortinarius species (Agaricales, Basidiomycetes) from tropical India and their phylogenetic position based on rDNA ITS sequences. Myc. Res. 2003, 107, 485-494. [CrossRef] [PubMed]

37. Soop, K.; Dima, B.; Cooper, J.A.; Park, D.; Oertel, B. A phylogenetic approach to a global supraspecific taxonomy of Cortinarius (Agaricales) with an emphasis on the southern mycota. Persoonia 2019, 42, 261-290. [CrossRef]

38. Suárez-Santiago, V.N.; Ortega, A.; Peintner, U.; López-Flores, I. Study on Cortinarius subgenus Telamonia section Hydrocybe in Europe, with especial emphasis on Mediterranean taxa. Mycol. Res. 2009, 113, 1070-1090. [CrossRef] [PubMed]

39. Frøslev, T.G.; Matheny, P.B.; Hibbett, D. Lower level relationships in the mushroom genus Cortinarius (Basidiomycota, Agaricales): A comparison of RPB1, RPB2, and ITS phylogenies. Mol. Phylogenet. Evol. 2005, 37, 602-618. [CrossRef]

40. Høiland, K.; Holst-Jensen, A. Cortinarius phylogeny and possible taxonomic implications of ITS rDNA sequences. Mycologia 2000, 92, 694-710. [CrossRef]

41. Liu, Y.J.; Rogers, S.O.; Ammirati, J.F. Phylogenetic relationships in Dermocybe and related Cortinarius taxa based on nuclear ribosomal DNA internal transcribed spacers. Can. J. Bot. 1997, 75, 519-532. [CrossRef]

42. Peintner, U.; Bougher, N.L.; Castellano, M.A.; Moncalvo, J.M.; Moser, M.; Trappe, J.M.; Vilgalys, R. Multiple origins of sequestrate fungi related to Cortinarius (Cortinariaceae). Am. J. Bot. 2001, 88, 2168-2179. [CrossRef] [PubMed]

43. Cabrera, A.L.; Willink, A. Biogeografía de América Latina. In Serie de Biología, Monografía 13; The General Secretariat of the Organization of American States: Washington, DC, USA, 1980; p. 122.

44. Maerz, A.; Paul, M.R. A Dictionary of Color, 1st ed.; Mc Graw-Hill Book Company Inc.: New York, NY, USA, 1930 ; p. 207.

45. Largent, D.L. How to Identify Mushrooms to Genus I: Macroscopic Features; Mad River Press: Eureka, CA, USA, $1986 ;$ p. 166.

46. Largent, D.L.; Johnson, D.; Watling, R. How to Identify Mushrooms to Genus III: Microscopic Features; Mad River Press: Eureka, CA, USA, 1986; p. 146.

47. White, T.J.; Bruns, T.; Lee, S.; Taylor, J.W. Amplification and direct sequencing of fungal ribosomal RNA genes for phylogenetics. In PCR Protocols: A Guide to Methods and Applications; Innis, M.S., Gelfand, D.H., Sninsky, J.J., White, T.J., Eds.; Academic Press: New York, NY, USA, 1990; pp. 315-322.

48. Matheny, P.B.; Liu, Y.J.J.; Ammirati, J.F.; Hall, B.D. Using RPB1 sequences to improve phylogenetic inference among mushrooms (Inocybe, Agaricales). Am. J. Bot. 2002, 89, 688-698. [CrossRef]

49. Stecher, G.; Tamura, K.; Kumar, S. Molecular Evolutionary Genetics Analysis (MEGA) for macOS. Mol. Biol. Evol. 2020, 37, 1237-1239. [CrossRef] [PubMed]

50. Ronquist, F.; Teslenko, M.; Van Der Mark, P.; Ayres, D.L.; Darling, A.; Hohna, S.; Larget, B.; Liu, L.; Suchard, M.A.; Huelsenbeck, J.P. Mrbayes 3.2: Efficient bayesian phylogenetic inference and model choice across a large model space. Syst. Biol. 2012, 61, 539-542. [CrossRef]

51. Everitt, B.S. An R and S-PLUS ${ }^{\circledR}$ Companion to Multivariate Analysis; USA. British Library Cataloguing in Publication Data; Springer: London, UK, 2005.

52. Di Rienzo, J.A.; Casanoves, F.; Balzarini, M.G.; Gonzalez, L.; Tablada, M.; Robledo, C.W. InfoStat versión 2017. Grupo InfoStat, FCA, Universidad Nacional de Córdoba, Argentina. 2017. Available online: http:/ / www.infostat.com.ar (accessed on 31 March 2021).

53. Soop, K.; Wallace, M.; Dima, B. New Cortinarius (Agaricales) species described from New Zealand. N. Z. J. Bot. 2018, 56, 163-182. [CrossRef]

54. Valenzuela, E.; Moreno, G.; Garnica, S.; Ramirez, C. Micosociología en bosques nativos de Nothofagus y plantaciones de Pinus radiata en la X Región de Chile: Diversidad y rol ecológico. Rev. Chil. Hist. Nat. 1998, 71, 133-146.

55. Niskanen, T. Cortinarius subgenus Telamonia p.p. in North Europe. Ph.D. Thesis, Helsinki University, Helsinki, Finland, 2008. Available online: https:/ /helda.helsinki.fi/handle/10138/22011 (accessed on 5 January 2020).

56. Tedersoo, L.; May, T.W.; Smith, M.E. Ectomycorrhizal lifestyle in fungi: Global diversity, distribution, and evolution of phylogenetic lineages. Mycorrhiza 2010, 20, 217-263. [CrossRef] [PubMed]

57. Kuhar, F.; Smith, M.E.; Mujic, A.; Truong, C.; Nouhra, E. A systematic overview of Descolea (Agaricales) in the Nothofagaceae forests of Patagonia. Fungal Biol. 2017, 121, 876-889. [CrossRef] [PubMed]

58. Truong, C.; Sanchez-Ramirez, S.; Kuhar, F.; Kaplan, Z.; Smith, M.E. The Gondwanan connection-Southern temperate Amanita lineages and the description of the first sequestrate species from the Americas. Fungal Biol. 2017, 121, 638-651. [CrossRef] [PubMed]

59. Trierveiler-Pereira, L.; Smith, M.E.; Trappe, J.M.; Nouhra, E.R. Sequestrate fungi from Patagonian Nothofagus forests: Cystangium (Russulaceae, Basidiomycota). Mycologia 2015, 107, 90-103. [CrossRef] [PubMed]

60. Truong, C.; Mujic, A.B.; Healy, R.; Kuhar, F.; Furci, G.; Torres, D.; Niskanen, T.; Sandoval-Leiva, P.A.; Fernandez, N.; Escobar, J.M.; et al. How to know the fungi: Combining field inventories and DNA-barcoding to document fungal diversity. New Phytol. 2017, 214, 913-919. [CrossRef] [PubMed]

61. Matheny, P.B.; Aime, M.C.; Bougher, N.L.; Buyck, B.; Desjardin, D.E.; Horak, E.; Kropp, B.R.; Lodge, D.J.; Soytong, K.; Trappe, J.M.; et al. Out of the Palaeotropics? Historical biogeography and diversification of the cosmopolitan ectomycorrhizal mushroom family Inocybaceae. J. Biogeogr. 2009, 36, 577-592. [CrossRef]

62. Bruns, T.D.; White, T.J.; Taylor, J.W. Fungal molecular systematics. Annu. Rev. Ecol. Syst. 1991, 22, 525-564. [CrossRef] 
63. Gardes, M.; Bruns, T.D. ITS primers with enhanced specificity for Basidiomycetes-Application to the identification of mycorrhizae and rusts. Mol. Ecol. 1993, 2, 113-118. [CrossRef]

64. Tedersoo, L.; Kõljalg, U.; Hallenberg, N.; Larsson, K.-H. Fine scale distribution of ectomycorrhizal fungi and roots across substrate layers including coarse woody debris in a mixed forest. New Phytol. 2003, 159, 153-165. [CrossRef] [PubMed]

65. Schoch, C.L.; Seifert, K.A.; Huhndorf, S.; Robert, V.; Spouge, J.L.; Levesque, A.C.; Chen, W.; Fungal Barcoding Consortium. Nuclear ribosomal internal transcribed spacer (ITS) region as a universal DNA barcode marker for Fungi. Proc. Natl. Acad. Sci. USA 2012, 109, 6241-6246. [CrossRef] [PubMed]

66. Pastor, N.; Chiapella, J.; Kuhar, F.; Mujic, A.B.; Crespo, E.M.; Nouhra, E.R. Unveiling new sequestrate Cortinarius species from northern Patagonian Nothofagaceae forests based on molecular and morphological data. Mycologia 2019, 111, 103-117. [CrossRef] [PubMed]

67. Garnica, S.; Schön, M.E.; Abarenkov, K.; Riess, K.; Liimatainen, K.; Niskanen, T.; Dima, B.; Soop, K.; Frøslev, T.G.; Jeppesen, T.S.; et al. Determining threshold values for barcoding fungi: Lessons from Cortinarius (Basidiomycota), a highly diverse and widespread ectomycorrhizal genus. FEMS Microbiol. Ecol. 2016, 92, 1-16. [CrossRef]

68. Truong, C.; Gabbarini, L.A.; Corrales, A.; Mujic, A.B.; Escobar, J.M.; Moretto, A.; Smith, M.E. Ectomycorrhizal fungi and soil enzymes exhibit contrasting patterns along elevation gradients in southern Patagonia. New Phytol. 2019, 222, 1936-1950. [CrossRef]

69. Liimatainen, K.; Niskanen, T.; Dima, B.; Kytövuori, I.; Ammirati, J.F.; Frøslev, T.G. The largest type study of Agaricales species to date: Bringing identification and nomenclature of Phlegmacium (Cortinarius) into the DNA era. Persoonia 2014, 33, 98-140. [CrossRef]

70. Ammirati, J.F.; Smith, A.H. Studies in the genus Cortinarius, III: Section Dermocybe, new North American species. Mycotaxon 1977, 5, 381-397.

71. Moser, M. Die Gattung Dermocybe (Fr.) Wünsche, (Die Hautköpfe). Schweiz. Z. Pilzkd. 1974, 52, $129-142$.

72. Danks, M.; Lebel, T.; Vernes, K. 'Cort short on a mountaintop'—Eight new species of sequestrate Cortinarius from sub-alpine Australia and affinities to sections within the genus. Persoonia 2010, 24, 106-126. [CrossRef] [PubMed]

73. Stefani, F.O.P.; Jones, R.H.; May, T.W. Concordance of seven gene genealogies compared to phenotypic data reveals multiple cryptic species in Australian dermocyboid Cortinarius (Agaricales). Mol. Phylogenet. Evol. 2014, 71, 249-260. [CrossRef]

74. Horak, E. New species of Dermocybe (Agaricales) from New Zealand. Sydowia 1988, 40, 81-112.

75. Soop, K. Contribution à l'étude de la mycoflore cortinarioïde de Nouvelle-Zélande. Bull. Soc. Mycol. France 2001, 117, 91-132. 